\title{
THE RELATIONSHIP BETWEEN ORGANISATIONAL STRATEGIC IT VISION AND CIO ROLES: ONE SIZE DOES NOT FIT ALL
}

\author{
Moyassar Al-Taie \\ University of Mosul - Iraq \\ University of Southern Queensland \\ moyassar_z_a@yahoo.com \\ Michael Lane \\ University of Southern Queensland \\ michael.lane@usq.edu.au \\ Aileen Cater-Steel \\ University of Southern Queensland \\ aileen.cater-steel@usq.edu.au
}

\begin{abstract}
The organisational strategic IT vision has been considered as a key contingency that affects the role of Information Technology (IT) leadership in organisations. Using the theoretical lens of the contingency approach to leadership, this study investigates the influence of strategic IT vision of an organisation on the Chief Information Officer (CIO) role and structural power. A large-scale survey was conducted with CIOs of Australian organizations. The results of the data analysis show that the Educator role of the CIO seems to be more important in organisations that articulated a 'transform' vision of IT compared to organisations that focus on IT for automation. The results also show that CIOs in organisations that strategically view IT as a transformation or informate-down orientation gave the role of Information Steward more attention than CIOs working in organisations where IT is viewed as a means to automate processes. The findings also show that there is significant positive association between the organisation's strategic IT vision and the CIO's structural power in terms of reporting structure and CIO job title. This study has implications for practitioners as the findings indicate the necessity for CIOs to align their roles with their firm's IT vision and suggest that Chief Executive Officers (CEOs) should empower their firm's CIOs in terms of their reporting structure and job title as the role of IT in the organisation progresses from the lower strategic vision of IT (automate) to the highest vision (transform).
\end{abstract}

Keywords: Contingency approach to leadership, Organisational strategic IT vision, Chief Information Officer (CIO) Role, CIO's reporting structure, CIO's job title, Australia.

\section{INTRODUCTION}

The strategic Information Technology (IT) vision is a key contingency affecting the role of IT leadership in organisations (Feeny, Edwards, and Simpson 1992; Kaarst-Brown 2005; Preston and Karahanna 2009; Smaltz , Sambamurthy, and Agarwal 2006; Smaltz 1999). The literature indicates that Chief Information Officers (CIOs) play multiple roles in their leadership of IT in an organisation (Agarwal and Beath 2007; Earl 1996; IBM 2009; McLean and Smits 1993; Peppard, Edwards, and Lambert 2011; Smaltz et al. 2006). These multiple roles can be grouped into operational (supply side) roles and strategic (demand side) roles (Broadbent and Kitzis 2005; Chen, Preston, and Xia 2010; Mark 
and Monnoyer 2004). Prior studies have acknowledged that IT is viewed by organisations in different ways and used for different purposes (Dahlbom and Mathiassen 1997; Kaarst-Brown 2005; Marchand 2007; McFarlan, McKenny, and Pyburn 1983; Schein 1989, 1992; Spitze and dePaschalis 2005). An extensive literature review indicates that few studies have examined the relationship between the strategic vision of IT in organisations and the multiple roles of the CIO in an organisation. While Smaltz (2000) and Li, Ding, and Wu (2012) found that CIOs in organisations that viewed IT as a transformation tool perceived their strategic CIO roles to be the most important, Periasamy and Seow (1998) reported conflicting points of view regarding the role of the CIO working in firms that espouse an 'automate' view of IT.

Other studies have failed to identify any significant effect of the organisational IT vision on CIOs' effectiveness in their roles (Brown 2006 ; Smaltz 1999). One study, conducted by Grover, Jeong, Kettinger, and Lee (1993) found that as the use of IT matures, the strategic role of the CIO does not become more important. There is also a lack of empirical research that has investigated the direct impact of the organisational view of IT on the CIO structural power in an organisation. Investigating the structural power of the CIO is crucial as the legitimacy of this executive manager has not been fully established in many organisations (Kaarst-Brown 2005). The lack of previous academic research in this area and the inconsistency in the results of previous empirical studies provides the justification for further investigation of the association between the strategic vision of IT in organisations on one hand and the role of the CIO and the structural power of the CIO job position in organisations on the other hand.

This study takes a novel approach to provide better understanding of the relationship between the strategic IT vision of the organisation and the CIO roles and their structural power. Based on the contingency approach to leadership, it is anticipated that the vision of IT for an individual organisation requires a CIO to adopt an appropriate configuration of roles that is aligned with the IT vision of an organisation. The mismatch between the IT vision of an organisation and the CIO roles could result in dire effects. For example, weak alignment between IT and the firm's strategy can lead to a reduction in the business value of IT, a decrease in the effectiveness of the CIOs, the corruption of the relationship between the CIO and the Chief Executive Officer (CEO). Finally, the misalignment of the current CIO roles with the IT vision of an organisation could threaten the survival of the CIO position in an organisation. Therefore, the CIO who is adopting the right roles and is given the required structural power to implement the vision of IT in an organisation is more likely to succeed and survive in the job. Hence, this study is important because it aims to investigate the relationship between the organisational IT vision and the configuration of CIO roles and structural power of a CIO in an organisation. The general research question investigated in this paper is as follows:

\section{Is the configuration of CIO roles and structural power of a CIO associated with an organisation's strategic vision of IT?}

This paper is structured as follows. First the relevant literature regarding the strategic IT vision in organisations and the CIO role is reviewed and a set of hypotheses is formulated from the literature. Next, the research methodology used in this study is described and justified. After that, the results of the data analysis of the survey responses of 162 CIOs are presented and discussed. Finally, implications of the key findings for existing theory and practice are discussed and some suggestions for future research are provided. 


\section{LITERATURE REVIEW}

\section{The contingency approach to leadership}

Since 1950s, empirical studies tend to show that a leader is required to behave in a flexible manner in an organisation, and needs to adopt the appropriate leadership style that fits with the situation (Tannenbaum and Schmidt 1957; Fiedler 1967; House and Mitchell 1974; Vroom and Yetton 1973; Hersey and Blanchard 1993). The contingency approach to leadership (also known as situational approach) proposes that different leaders' behaviours are effective in different situations. Therefore, leadership from the contingency approach perspective is a dynamic process that implies different roles, style, or behaviour in different organisational situations. These perspectives refute the notion of "one size fits all" as there is no optimal leadership style appropriate to all situations.

Early research regarding the IT leadership conducted by Rockart, Ball, and Bullen (1982) emphasized the importance of studying the organisational contingencies that shape the CIO role in an organisation. It is anticipated that studying the CIO role without considering the organizational context can result in misunderstanding that crucial role. This study investigates how different organisational visions of IT articulated by modern organisations can affect the CIOs' roles and their structural power.

\section{Strategic IT vision}

Strategic IT vision refers to the shared, aspired state of the role that IT should play in the firm (Robbins and Duncan 1988; Zmud 1988 as cited in Armstrong and Sambamurthy1999). It is worth mentioning that different names have been used interchangeably for this construct such as the CEO's basic assumption about IT (Kaarst-Brown 2005; Schein 1989, 1992); IS/IT orientation (Weill and Broadbent 1998; Teo and Too 2000); IS/IT role (Chen, Mocker, Preston, and Tuebner 2010; Feeny et al. 1992; Hallikainen, Hu, Frisk, Päivärinta, Eikebrokk, and Nurmi 2006; Ramakrishna and Lin 2002; Richardson and Zmud 2002); organisation's attitude to IT (Earl 1996); and the main purpose of IT (Weiss, Thorogood and Clark 2006). The previous literature summarised in Table 1 highlights 10 different typologies for understanding how the role of IT could be viewed in an organisation.

\begin{tabular}{|l|l|}
\hline Organisational views and assumptions about the role of IT & References \\
\hline Support; Factory; Strategic; and Turnaround & McFarlan et al. 1983 \\
\hline $\begin{array}{l}\text { Exploiter/innovator; Competitor/early adopter; and Participant/ effective } \\
\text { or efficient follower }\end{array}$ & Cash et al. 1988 \\
\hline Automate; and Informate & Zuboff 1985 \\
\hline Automate; Informate-down; Informate-up; and Transform & Schein 1989, 1992 \\
\hline Automate; Informate; and Transform & Venkataraman 1991 \\
\hline Build things; Help people; and Change things & Dahlbom et al. 1997 \\
\hline Support tool; Critical resource; Means of transformation; and Unclear & Earl 1996 \\
\hline Utilitarian; Strategic & $\begin{array}{l}\text { Weill and Broadbent } \\
1998\end{array}$ \\
\hline $\begin{array}{l}\text { Necessary Evil; Support not a partner; IT rules!; Business can do IT } \\
\text { better; and Equal partner }\end{array}$ & Kaarst-Brown 2005 \\
\hline Technical resource; Business enabler; and Strategic weapon & Weiss et al. 2006 \\
\hline $\begin{array}{l}\text { IT Doesn't matter; IT Pushes the business; Business Pushes IT; and IT } \\
\text { Does matter }\end{array}$ & Marchand 2007 \\
\hline
\end{tabular}

Table 1. Literature Summary- Main IT Role Typologies (Source: developed for this study) 
The strategic IT vision typology (Schein 1989, 1992) has been widely adopted by previous IS researchers (e.g. Armstrong and Sambamurthy 1999; Bassellier, Reich,and Benbasat 2001; Feeny et al. 1992; Hallikainen et al. 2006; Sherer 2004; Smaltz 2000; Smaltz et al. 2006; Smaltz 1999; Tripp 2008). The strategic IT vision of an organisation (Schein 1989, 1992) can be classified into four distinct views: automate, informate-down, informate-up, and transform. A brief description of each of these views is provided in Table 2.

\begin{tabular}{|l|l|l|}
\hline Vision & Description & Purpose (Feeny 1997) \\
\hline Automate & $\begin{array}{l}\text { The potential of IT is cost saving or quality } \\
\text { improvement through automation. The role of IT is } \\
\text { to replace expensive, unreliable human labour, or at } \\
\text { least transform its productivity. }\end{array}$ & $\begin{array}{l}\text { Cost-displacement and } \\
\text { efficiency }\end{array}$ \\
\hline Informate-down & $\begin{array}{l}\text { The potential of IT is to empower employee driven } \\
\text { performance improvement. The role of IT is to } \\
\text { provide data and transaction that yield a far fuller } \\
\text { picture at 'operator' level, with members of the } \\
\text { staff gaining greater insight into their own } \\
\text { activities. }\end{array}$ & Empower employees \\
\hline Informate-up & $\begin{array}{l}\text { The potential of IT is to increase managerial control } \\
\text { of the organisation. The role of IT is to provide data } \\
\text { and transaction that allow management to have } \\
\text { more clear and organized views of the state and } \\
\text { dynamics of the organisation. }\end{array}$ & $\begin{array}{l}\text { Increase management } \\
\text { control }\end{array}$ \\
\hline Transform & $\begin{array}{l}\text { The potential of IT is to transform the organisation. } \\
\text { The role of IT is to fundamentally change the } \\
\text { organisation and /or industry through new products } \\
\text { and services often including redefinition of } \\
\text { relationships with the organisation's customers and } \\
\text { /or suppliers. }\end{array}$ & $\begin{array}{l}\text { Achieve radical change } \\
\text { in some aspect of } \\
\text { business }\end{array}$ \\
\hline
\end{tabular}

Table 2. Organisational Strategic Views of the Role of IT (Sources: Feeny (1997); Feeny et al. (1992); Schein (1989); Smaltz (1999))

\section{Chief Information Officer (CIO) Roles}

The term 'role' refers to an 'organized set of behaviours belonging to an identifiable office or position' (Sarbin and Alan 1968). From the literature it is evident that there are four main configurations of roles that have been developed for general managers over the last four decades: Mintzberg's managerial roles; PAIE (Producer, Administrator, Entrepreneur, and Integrator); CVF (Competing Values Framework); and the integrated model of executive leadership roles. Table 3 summarizes these four key typologies. 


\begin{tabular}{|c|c|c|c|}
\hline Typology/Configuration & $\begin{array}{l}\text { Title used in } \\
\text { Literature }\end{array}$ & $\begin{array}{l}\text { Number } \\
\text { of Roles }\end{array}$ & Roles Label \\
\hline Mintzberg 1973 & $\begin{array}{l}\text { Mintzberg's } \\
\text { Managerial } \\
\text { Roles }\end{array}$ & 10 & $\begin{array}{l}\text { Interpersonal roles: Figurehead, } \\
\text { Leader, Liaison } \\
\text { Informational roles: Monitor, } \\
\text { Disseminator, Spokesperson } \\
\text { Decisional roles: Entrepreneur, } \\
\text { Disturbance hander, Resource } \\
\text { allocator, Negotiator }\end{array}$ \\
\hline Adizes 1976; Adizes 2004 & PAEI & 4 & $\begin{array}{l}\text { Producer, Administrator, } \\
\text { Entrepreneur, Integrator }\end{array}$ \\
\hline $\begin{array}{l}\text { Quinn, Faerman, Thompson, } \\
\text { McGrath, \& Clair 2006; } \\
\text { Quinn \& Rohrbaugh 1981; } \\
\text { Quinn \& Rohrbaugh } 1983\end{array}$ & $\begin{array}{l}\text { Competing } \\
\text { Value } \\
\text { Framework } \\
\text { CVF }\end{array}$ & 8 & $\begin{array}{l}\text { Mentor, Facilitator, Innovator, } \\
\text { Broker, Monitor, Coordinator, } \\
\text { Producer, Director }\end{array}$ \\
\hline Hart \& Quinn 1993 & $\begin{array}{l}\text { Integrated } \\
\text { model of } \\
\text { executive } \\
\text { leadership } \\
\text { roles }\end{array}$ & 4 & $\begin{array}{l}\text { Vision setter, Motivator, Analyser, } \\
\text { Task master }\end{array}$ \\
\hline
\end{tabular}

Table 3. Key Classic Managerial Roles Typologies

\section{The CIO role based on the classic managerial roles configurations}

Since the emergence of the CIO role in the early 1980s (Synnott 1987; Synnott et al. 1981) much has been written about it (Chen and Preston 2007; Fisher 2003; Karimi , Gupta, and Somers 1996; Stephens, Ledbetter, Mitra, and Ford, 1992). Brown (1993) asserts that prior theories regarding managerial work and leadership are applicable to the CIO role and it could be a useful base to build on provided the CIO is a general manager. Consequently, many researchers have attempted to apply the roles developed for general managers to the position of CIO. Twelve key empirical studies that adopted a classical managerial roles configuration in order to gain a better understanding of the CIO role(s) are summarised in Table 4.

Some interesting observations can be made on closer examination of the 12 empirical studies listed in Table 4. First, it is confirmed that applying general managers and leadership frameworks to the CIO role provides a greater understanding of the importance of CIO roles. Second, it appears that the CIO role is evolving from focusing on communication-based roles such as spokesman and liaison (Grover et al. 1993) to play a more strategic role focusing on change and innovation as an entrepreneur in the organisation (Gottschalk 2000b; Karlsen, Gottschalk, and Andersen 2002; Lineman 2006; Milliron 2008). Furthermore, it is clear that the Mintzberg (1973) framework that was used in 10 out of 12 CIO roles empirical studies reviewed (Carter, Grover, and Thatcher 2011; Gottschalk 2000a, 2000b; Grover et al. 1993; Karlsen et al. 2002; Lineman 2006; Milliron 2008; Stephens 1995; Yang 2008), was the most widely used framework. Moreover, the extensive review of the relevant literature indicated a gap in the CIO literature that needs to be addressed as the vast majority of previous empirical studies examining the CIO roles in organisations were based on Mintzberg's framework whereas almost none used any of the other three key management roles typologies of Adizes (1976, 2004), Quinn et al. (2006, 1981, 1983), and Hart and Quinn (1993). 


\begin{tabular}{|c|c|c|c|c|}
\hline Reference & Methodology & Sample & Country & Important Roles Reported \\
\hline $\begin{array}{l}\text { Grover et } \\
\text { al. } 1993\end{array}$ & $\begin{array}{l}\text { Quantitative - } \\
\text { Survey }\end{array}$ & $\begin{array}{l}71 \text { CIOs and IS } \\
\text { middle managers }\end{array}$ & USA & Spokesperson and liaison roles \\
\hline $\begin{array}{l}\text { Stephen } \\
1995\end{array}$ & Observation & $\begin{array}{l}5 \text { CIOs from } \\
\text { different industries }\end{array}$ & USA & $\begin{array}{l}\text { Occurrence frequency : resource } \\
\text { allocator, monitor, and } \\
\text { distributer handler } \\
\text { Time spent: resource allocator, } \\
\text { entrepreneur, distributer } \\
\text { handler, and monitor roles }\end{array}$ \\
\hline $\begin{array}{l}\text { Gottschalk } \\
\text { 2000a }\end{array}$ & $\begin{array}{l}\text { Quantitative - } \\
\text { Survey }\end{array}$ & $101 \mathrm{IS} / / \mathrm{IT}$ leaders & Norway & $\begin{array}{l}\text { New IS/IT leaders more time in } \\
\text { Mintzberg's informational roles } \\
\text { than established IS/IT leaders. }\end{array}$ \\
\hline $\begin{array}{l}\text { Gottschalk } \\
2000 \mathrm{~b}\end{array}$ & $\begin{array}{l}\text { Quantitative - } \\
\text { Survey }\end{array}$ & $101 \mathrm{IS} / / \mathrm{IT}$ leaders & Norway & $\begin{array}{l}\text { Strategic responsibilities and IS } \\
\text { stage of growth influences } \\
\text { extent of informational roles. } \\
\text { Extent chief executives uses IT } \\
\text { influences extent of decisional } \\
\text { roles, and extent which } \\
\text { subordinates use IT influences } \\
\text { extent of interpersonal roles. }\end{array}$ \\
\hline $\begin{array}{l}\text { Gottschalk } \\
2002\end{array}$ & $\begin{array}{l}\text { Quantitative - } \\
\text { Survey }\end{array}$ & 128 & Norway & Entrepreneur \\
\hline $\begin{array}{l}\text { Karlsen, } \\
\text { Gottschalk } \\
\text { \& Andersen } \\
2002\end{array}$ & $\begin{array}{l}\text { Quantitative - } \\
\text { Survey }\end{array}$ & $\begin{array}{l}128 \text { IT executives } \\
\text { and } 80 \text { IT project } \\
\text { managers }\end{array}$ & Norway & $\begin{array}{l}\text { For IT leaders: monitor } \\
\text { For IT project managers: } \\
\text { leaders, resource allocator, and } \\
\text { entrepreneur }\end{array}$ \\
\hline $\begin{array}{l}\text { Lineman } \\
2005\end{array}$ & $\begin{array}{l}\text { Quantitative - } \\
\text { Survey }\end{array}$ & $\begin{array}{l}232 \text { higher } \\
\text { education CIOs }\end{array}$ & USA & $\begin{array}{l}\text { Entrepreneur, resource } \\
\text { allocator, and leader }\end{array}$ \\
\hline $\begin{array}{l}\text { Gottschalk } \\
\text { \& Karlsen } \\
2005\end{array}$ & $\begin{array}{l}\text { Quantitative - } \\
\text { Survey }\end{array}$ & $\begin{array}{l}80 \text { IT leaders of } \\
\text { firms with internal } \\
\text { IT projects }+84 \text { IT } \\
\text { leaders of firms } \\
\text { with outsourcing } \\
\text { projects }\end{array}$ & Norway & $\begin{array}{l}\text { In firms with internal IT project: } \\
\text { leader } \\
\text { In firms with outsourcing IT } \\
\text { project: spokesman }\end{array}$ \\
\hline Yang 2008 & $\begin{array}{l}\text { Quantitative - } \\
\text { Survey }\end{array}$ & $\begin{array}{l}\text { IT managers of } \\
\text { financial industry }\end{array}$ & Taiwan & Liaison and spokesperson roles \\
\hline $\begin{array}{l}\text { Milliron } \\
2008\end{array}$ & $\begin{array}{l}\text { Mixed Interviews } \\
+ \text { Survey }\end{array}$ & $\begin{array}{l}10 \text { CIOs of } \\
\text { community colleges }\end{array}$ & USA & $\begin{array}{l}\text { Monitor, liaison, and } \\
\text { entrepreneur roles }\end{array}$ \\
\hline $\begin{array}{l}\text { Tufts \& } \\
\text { Jacobson } \\
2010\end{array}$ & $\begin{array}{l}\text { Q-Methodology } \\
\text { based on the } \\
\text { CVF } 8 \text { roles } \\
\text { survey }\end{array}$ & 67 Public CIOs & USA & $\begin{array}{l}\text { Results oriented pragmatist; } \\
\text { Compassionate managers; } \\
\text { Leading edge powerbroker; and } \\
\text { Goal oriented powerbroker }\end{array}$ \\
\hline $\begin{array}{l}\text { Carter, } \\
\text { Grover, \& } \\
\text { Bennett } \\
2011 \\
\end{array}$ & $\begin{array}{l}\text { Quantitative - } \\
\text { Survey }\end{array}$ & 45 CIOs & USA & Monitor and Spokesperson \\
\hline
\end{tabular}

Table 4. Empirical CIO Studies based on Classical Managerial Roles Typologies 


\section{The CIO distinctive roles configurations}

Some Information Systems scholars have attempted to suggest other distinctive roles for the CIO which differ from the classic managerial roles discussed in the previous section and consider the unique characteristics required for this role. This different approach to conceptualising the CIO roles was based on the fact that Mintzberg (1971) himself has asserted that all managers are indeed specialists and therefore their roles tend to be dependent on the functional area they lead. As part of the extensive review of the literature, 24 studies that specified configurations of CIO roles over the last couple of decades are summarised in Table 5.

\begin{tabular}{|c|c|c|c|c|}
\hline Reference & Methodology & Country & Roles & Citations \\
\hline Dixon \& John 1989 & Conceptual & USA & 3 & 100 \\
\hline Klenke 1993 & Conceptual & USA & 4 & 14 \\
\hline McLean \& Smits 1993 & Conceptual & USA & 4 & 5 \\
\hline Klenke 1996 & Conceptual & USA & 4 & 4 \\
\hline CSC 1996 & Conceptual & UK & 6 & Not available \\
\hline Feeny 1997 & Qualitative (Interviews) & UK & 4 & 8 \\
\hline Earl 1998 & Qualitative (Interviews) & UK & 8 & 32 \\
\hline Smaltz 1999 & Quantitative (Survey) & USA & 6 & 12 \\
\hline McLean \& Smits 2003 & Qualitative (Interviews) & USA & 4 & Not available \\
\hline Cash \& Pearlson 2004 & Conceptual & USA & 5 & 7 \\
\hline Perchthold \& Sutton 2005 & Conceptual & USA & 3 & Not available \\
\hline $\begin{array}{l}\text { Sojer, Schlager, \& Locher } \\
2006\end{array}$ & Quantitative (Surveys) & USA & 4 & 7 \\
\hline $\begin{array}{l}\text { Smaltz, Sambamurthy,\& } \\
\text { Agarwal } 2006\end{array}$ & Quantitative (Survey) & USA & 6 & 88 \\
\hline Agarwal \& Beath 2007 & Qualitative (Interviews) & USA & 7 & 5 \\
\hline $\begin{array}{l}\text { Tansley, Loughran. } \\
\text { Edwards, Lammert, \& } \\
\text { Peppard } 2008\end{array}$ & $\begin{array}{l}\text { Qualitative (Semi- } \\
\text { structured Interviews) }\end{array}$ & UK & 5 & Not available \\
\hline Weiss \& Adams 2010 & $\begin{array}{l}\text { Mixed (online Survey+ } \\
\text { interviews) }\end{array}$ & USA & 3 & 2 \\
\hline $\begin{array}{l}\text { Wu, Chen, \& } \\
\text { Sambamurthy } 2008\end{array}$ & Quantitative (Survey) & $\begin{array}{l}\text { Taiwan \& } \\
\text { China }\end{array}$ & 8 & 6 \\
\hline IBM 2009 & Qualitative (Interviews) & $\begin{array}{l}\text { Global } 78 \\
\text { countries }\end{array}$ & 3 pairs & Not available \\
\hline Chun \& Moony 2009 & $\begin{array}{l}\text { Mixed (Secondary data }+ \\
\text { interviews) }\end{array}$ & USA & 4 & 36 \\
\hline CIO Magazine 2009 & Quantitative (Survey) & USA & 3 & Not available \\
\hline $\begin{array}{l}\text { Peppard, Edwards, \& } \\
\text { Lambert } 2011\end{array}$ & $\begin{array}{l}\text { Qualitative (Semi- } \\
\text { structured Interviews) }\end{array}$ & UK & 5 & 4 \\
\hline Chen \& Wu 2011 & Quantitative (Survey) & $\begin{array}{l}\text { Taiwan \& } \\
\text { China }\end{array}$ & 8 & 5 \\
\hline Nicolet 2011 & $\begin{array}{l}\text { Mixed (Survey }+ \\
\text { Interviews) }\end{array}$ & USA & 6 & 0 \\
\hline McLean \& Smits 2012 & Qualitative (Interviews) & USA & 4 & 0 \\
\hline
\end{tabular}

Table 5. Summary of Previous Studies of CIO Key Roles Configurations 
Several important conclusions can be drawn from these 24 studies of the role configurations of CIOs. First, the CIO role configurations studies can be classified as conceptual ( $N=7)$ and empirical $(\mathrm{N}=17)$. The vast majority of the early research studies on the CIO role presented in Table 5 were conceptual. The seventeen studies on CIO role configurations that were empirically based can in turn be categorised by their methodology into three groups: quantitative $(\mathrm{N}=7)$; qualitative $(\mathrm{N}=7)$; and mixed methodology $(\mathrm{N}=3)$. Two thirds of these studies on CIO role configurations were conducted in the USA $(\mathrm{N}=15)$, nearly one third in the UK $(\mathrm{N}=5)$, with the rest conducted in China and Taiwan $(\mathrm{N}=2)$ or worldwide $(\mathrm{N}=1)$. The number of suggested CIO roles in each of these 24 studies ranges from three to eight. Studies with a large number of roles in configurations (7 and 8 roles) tend to break down the main roles into much more specific roles for the sake of further explanation, while studies with fewer CIO roles in configurations ( 3 and 4 roles) tend to merge two or more key CIO roles for the sake of parsimony. Earlier and later studies presented in Table 5 include both operational (supply side) roles and strategic (demand side) roles and indicate that the shift of CIO role from a largely technical and supply side role to a more strategic and demand side role started back in the late 1980s. These 24 studies of CIO role configurations confirmed that the CIO has multiple roles (a configuration of roles) and not one or two specific roles. IS scholars have given different names to the CIO roles. The most cited CIO role configuration based on the data provided by Google Scholar (as December 2012) is Smaltz et al.'s (2006) model of six key roles, followed by Chun and Mooney's (2009) configuration of four key roles. Table 6 provides brief definitions of these six roles in the CIO roles configuration model developed and validated by Smaltz et al. (2006).

\begin{tabular}{|l|l|}
\hline Supply Side Roles & Demand Side Roles \\
\hline $\begin{array}{l}\text { Educator: The role of the CIO as an IT } \\
\text { missionary, who provides insight and } \\
\text { understanding about key information } \\
\text { technologies to raise top management } \\
\text { savviness, awareness, and appreciation of IT } \\
\text { and help them to make appropriate judgments } \\
\text { about the business value of IT and wise IT } \\
\text { investment decisions. }\end{array}$ & $\begin{array}{l}\text { Strategist: The organisational desire for the } \\
\text { CIO to be an effective business partner and help } \\
\text { their organisation leverage valuable } \\
\text { opportunities for IT-based innovation and } \\
\text { business process redesign. }\end{array}$ \\
\hline $\begin{array}{l}\text { Information Steward: The desirability of the } \\
\text { CIO to be an organisational steward for high } \\
\text { quality data and operationally reliable systems. }\end{array}$ & $\begin{array}{l}\text { Relationship Architect: The desirability of a } \\
\text { CIO to build relationships both across the } \\
\text { enterprise as well as outside the enterprise with } \\
\text { key IT service providers. }\end{array}$ \\
\hline $\begin{array}{l}\text { Utility Provider: The role of the CIO as a } \\
\text { builder of sustaining solid, dependable, and } \\
\text { responsive IT infrastructure services. }\end{array}$ & $\begin{array}{l}\text { Integrator: The desirability of the CIO } \\
\text { providing leadership in enterprise-wide } \\
\text { integration of processes, information, and } \\
\text { decision-support as digital options for the } \\
\text { business }\end{array}$ \\
\hline
\end{tabular}

Table 6. Smaltz et al.’s (2006) Six Key CIO Roles (Source: Smaltz et al. 2006)

After rational examination and comparison of the quantitative studies of CIO role configurations, this research adopted the six CIO roles configuration developed by Smaltz et al. (2006) for several reasons. First, this CIO roles configuration model was developed from the comprehensive inventory of CIO roles identified from previous literature and empirical data obtained from in-depth interviews with CIOs and top management members. Second, it represents a comprehensive configuration that accommodates all of other empirical configurations previously identified as shown in Table 7. Also, despite the fact that this configuration of CIO roles was developed within the healthcare sector, the CIO roles that emerged were similar to the ones that have been identified in the existing literature in general (Strickland 2011). Furthermore, Agarwal and Beath (2007) found that all of the roles included in this 
CIO roles configuration were important in grooming the future CIOs regardless of their industry. Moreover, this configuration has been proved to be a valid typology within the Australian context (Seddon, Walker, Reynolds, and Willcocks 2008). What is more, Smaltz et al. (2006) classified these six roles into two groups: supply side roles (utility provider, information steward, and educator) and demand side roles (integrator, relationship architect, and strategist) following the modern classification of the CIO roles proposed by IS scholars such as Mark et al. (2004) and Broadbent and Kitzis (2005). Furthermore, this CIO roles configuration has been measured by a survey instrument that demonstrated high validity and reliability (Chen et al. 2010; Chen and Wu 2011; Li et al. 2012; Wu, Chen, and Sambamurthy 2008). Finally, the survey instrument for this CIO configuration is concise which is crucial as the targeted survey respondent is the most senior IT executive in the organisations. These managers are usually extremely busy and less likely to complete a lengthy questionnaire. 


\begin{tabular}{|c|c|c|c|c|c|c|}
\hline \multirow[t]{2}{*}{ Reference } & \multicolumn{3}{|c|}{ Three Demand Side Roles } & \multicolumn{3}{|c|}{ Three Supply Side Roles } \\
\hline & Strategist & $\begin{array}{l}\text { Relationship } \\
\text { Architect }\end{array}$ & Integrator & Educator & $\begin{array}{l}\text { Information } \\
\text { Steward }\end{array}$ & $\begin{array}{l}\text { Utility } \\
\text { Provider }\end{array}$ \\
\hline Feeny 1997 & $\begin{array}{l}\text { System } \\
\text { thinker }\end{array}$ & $\begin{array}{l}\text { Relationship } \\
\text { builder }\end{array}$ & - & - & $\begin{array}{l}\text { Technical } \\
\text { Virtuoso }\end{array}$ & $\begin{array}{l}\text { Supply } \\
\text { manager }\end{array}$ \\
\hline Earl 1996 & \begin{tabular}{|l|} 
Visionary / \\
Systems \\
thinker
\end{tabular} & $\begin{array}{l}\text { Relationship } \\
\text { builder / Alliance- } \\
\text { manager }\end{array}$ & - & - & $\begin{array}{l}\text { Tactician } \\
\text { /Reformer }\end{array}$ & $\begin{array}{l}\text { Deliverer } \\
\text { /Architect }\end{array}$ \\
\hline $\begin{array}{l}\text { McLean \& } \\
\text { Smits 1993; } \\
\text { 2003; } 2012\end{array}$ & $\begin{array}{l}\text { Strategist/ } \\
\text { Innovator }\end{array}$ & $\begin{array}{l}\text { Innovator/ } \\
\text { Enabler }\end{array}$ & Innovator & - & Enabler & Technologist \\
\hline $\begin{array}{lll}\text { Sojer } & \text { et } & \text { al. } \\
2006 & & \end{array}$ & Driver & Enabler & - & - & - & $\begin{array}{l}\text { Supporter/ } \\
\text { Cost cutter }\end{array}$ \\
\hline $\begin{array}{l}\text { Agarwal \& } \\
\text { Beath } 2007\end{array}$ & Strategist & $\begin{array}{l}\text { Relationship } \\
\text { Architect }\end{array}$ & $\begin{array}{l}\text { Integrator / } \\
\text { Leader }\end{array}$ & Educator & $\begin{array}{l}\text { Information } \\
\text { Steward/ } \\
\text { Leader }\end{array}$ & $\begin{array}{l}\text { Utility } \\
\text { Provider }\end{array}$ \\
\hline IBM 2009 & \begin{tabular}{|l|}
$\begin{array}{l}\text { Savvy value } \\
\text { creator }\end{array}$ \\
\end{tabular} & $\begin{array}{l}\text { Collaborative } \\
\text { business leader }\end{array}$ & $\begin{array}{l}\text { Insightful } \\
\text { visionary }\end{array}$ & - & - & - \\
\hline $\begin{array}{|ll|}\text { Chun } & \& \\
\text { Mooney } & \\
2009 & \\
\end{array}$ & $\begin{array}{l}\text { Innovator \& } \\
\text { Creator }\end{array}$ & - & $\begin{array}{l}\text { Opportunit } \\
\text { y Seeker }\end{array}$ & - & $\begin{array}{l}\text { Triage } \\
\text { Nurse }\end{array}$ & $\begin{array}{l}\text { Landscape } \\
\text { Cultivator }\end{array}$ \\
\hline $\begin{array}{|lr|}\text { Weiss } & \& \\
\text { Adams } & 2010 \\
\end{array}$ & \begin{tabular}{|l|} 
Change agent \\
$/ \quad$ Business \\
expert
\end{tabular} & Change agent & $\begin{array}{l}\text { Technologi } \\
\text { st }\end{array}$ & - & - & Technologist \\
\hline $\begin{array}{l}\text { Peppard et al. } \\
\text { 2011; } \\
\text { Tansley, } \\
\text { Loughran, } \\
\text { Edwards, } \\
\text { Lambert, \& } \\
\text { Peppard } \\
2008\end{array}$ & Innovator & - & Facilitator & Evangelist & - & \begin{tabular}{|lr} 
Utility & IT \\
Director/ & \\
Agility & IT \\
director &
\end{tabular} \\
\hline $\begin{array}{l}\text { Chen \& Wu } \\
\text { 2011; Wu et } \\
\text { al. } 2008\end{array}$ & \begin{tabular}{|l|} 
Business \\
visionary, \\
business \\
system \\
thinker, \\
entrepreneur; \\
\& value \\
configure \\
\end{tabular} & \begin{tabular}{l}
\multicolumn{3}{l}{ Relationship } \\
builder ; value \\
configure; $\quad$ \& \\
Informed buyer
\end{tabular} & $\begin{array}{l}\text { Organisati } \\
\text { onal } \\
\text { designer } \\
\text { (Coordinat } \\
\text { ing) }\end{array}$ & - & $\begin{array}{l}\text { Organisatio } \\
\text { nal designer } \\
\text { (Staff) }\end{array}$ & $\begin{array}{l}\text { Infrastructure } \\
\text { builder }\end{array}$ \\
\hline Nicolet 2011 & Strategist & - & $\begin{array}{l}\text { Facilitator } \\
\text { / Manager }\end{array}$ & Educator & - & $\begin{array}{l}\text { Technologist } \\
\text { / } \\
\text { Implementer }\end{array}$ \\
\hline
\end{tabular}

Table 7. Mapping of Six CIO Roles Configuration (Smaltz et al. 2006) with other Researchers' CIO Roles Configurations 


\section{RESEARCH HYPOTHESES DEVELOPMENT}

\section{The relationship between the IT vision and CIO role}

The prior literature emphasised two central facts regarding the roles of CIOs. The first is that CIOs perform a configuration of roles rather than one specific role (Agarwal and Beath 2007; Chen and Wu 2011; Earl 1996; Smaltz et al. 2006), while the second fact acknowledges that the importance of these roles differs according to the organisational contingency (Earl 1996; Kaarst-Brown 2005; Peppard et al. 2011; Rockart, Ball, and Bullen 1982; Smaltz et al. 2006). Some conceptual and empirical studies anticipated that the strategic IT vision of the firm may affect the CIO's role (Broadbent and Kitzis 2005; Dahlbom and Mathiassen1997; Kaarst-Brown 2005; Marchand 2007; Spitze and dePaschalis 2005). Teo and Too (2000) asserted that the organisation's strategic IT vision evolves in stages from automate to informate and finally, to transform, thus firms progress along an evolutionary path that parallels with the maturing of their deployment of IT. McLean and Smits (2003) confirmed that the role of CIO has evolved and expanded into a number of roles in parallel with the evolution of the role of IT in organisations starting with the technologist role, then to be an enabler, then an innovator, and lastly as a strategist role. Results from a recent empirical study of 129 CIOs and senior business executives from China and Taiwan (Li et al. 2012) indicate that the strategic IT vision has a significant moderating effect on the relationship between CIO strategic roles' effectiveness and the innovative usage of IS. An empirical study of 168 senior IT executives in the healthcare sector in the USA revealed that CIO roles as business partner (strategist) and integrator were significantly more important to organisations that expressed a 'transform' vision of IT (Smaltz 2000). Hence, the literature provides support for the following hypothesis:

H1: The perceived importance of each CIO role (strategist, integrator, relationship architect, educator, utility provider, and information steward) differs according to the organisation's strategic IT vision (automate, informate-down, informate-up, and transform).

\section{The relationship between the IT vision and CIO structural power}

The CIO's structural power refers to the CIO's level of legitimate power in their formal position within the hierarchy of the organisation (Chen et al. 2010). For the purpose of this research two variables will be used to measure the CIO's structural power: the CIO's reporting structure and the CIO's job title in an organisation. The literature suggested that a shared conception of the role of IT in an organisation is the key to an excellent relationship between the CEO and the CIO (Feeny et al. 1992) and it was critical to create and implement IS strategic alignment in an organisation (Preston et al. 2009). Furthermore, it has been found that the CIOs with higher reporting levels had greater influence and control over the extent of IT strategy implementation (Gottschalk 1999). Preston, Chen, and Leidner (2008) found that CIO structural power, measured by reporting structure, is positively associated with the CIO's level of strategic decision-making authority in an organisation. Cohen and Dennis (2010) found a significant relationship between the CIO reporting level and the CIO organisational positioning. Other studies have confirmed the significant relationship between the rank of IT leader and the organisation's IT strategic orientation (Grover et al. 1993; Raghunathan and Raghunathan 1989) which indicates that the higher the rank of a CIO in an organisation structure, the higher the vision of IT is ranked in an organisation. Karimi et al. (1996) emphasise that the IT leader's rank and role must align with the firm's competitive strategy. Saldanha and Krishnan (2011) found that IT-enabled business innovation is more likely when the CIO reports to the CEO. It is argued that the CIOs reporting structure should align with the organisational main purpose of IT (Leonard 2007). Banker, Hu, Pavlou, and Luftman (2011) found that the firm's strategic positioning (differentiation or cost leadership) and IT orientation are a primary determinant of its CIO reporting structure. A CIO is more likely to report to the CEO and have a high level job title when IT is considered to be a strategic enabler of organisational strategy whereas a CIO 
is more likely to report to the CFO and have a lower level job title when IT is considered to be mainly a way to reduce costs in an organisation. The literature provides support for the following hypothesis:

H2: The IT leader's structural power is positively associated with the firm's strategic IT vision. Figure 1 illustrates the research model showing the hypotheses that the organisational vision of IT is associated with the CIO's role and their structural power.

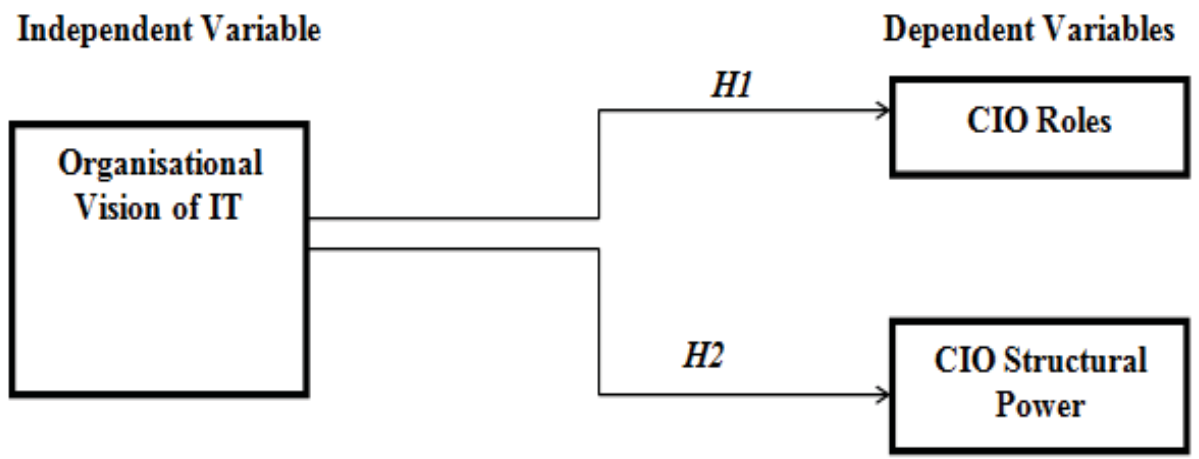

Figure 1 Research Model

\section{METHODOLOGY}

The aim of this study is to examine the relationship between the strategic vision of IT in an organisation and the configuration of CIO roles and structural power of the CIO. A quantitative approach based on a postal mail survey was chosen in order to establish generalizability, allow replication, and gain adequate statistical power (Straub 1989). Senior IT executives (CIOs) were the targeted survey respondent for this study. The rationale behind choosing the $\mathrm{CIO}$ as the most appropriate person in an organisation to provide answers on the research constructs (CIO roles, strategic vision of IT, CIO structural power) was that they are the most experienced and knowledgeable persons in terms of their roles, position in the organisation and their organisation's view of IT. Thus CIOs can provide appropriate responses to the survey questionnaire leading to accurate results.

\section{Research Measures}

The questionnaire used in this study comprises three sections (see Appendix A). The first section presents the strategic IT vision scale developed by Feeny et al. (1992) based on Schein's (1989, 1992) typology. This scale is ordinal and gives the respondents four brief statements that describe four visions of the role of IT in an organisation (automate, informate-down, informate-up, and transform). The respondents were asked to choose one option that best describes their firm's vision of IT. This measure was successfully adopted by previous researchers (e.g., Armstrong and Sambamurthy 1999; Feeny et al. 1992; Smaltz 2000; Smaltz et al. 2006; Smaltz 1999) whereas we did not find any research that used the scales developed by Subramanian and Nosek (1993) and Ramakrishna and Lin (2002).

The second section of the research questionnaire includes the CIO role expectations instrument developed by Smaltz et al. (2006). This instrument has chosen after a rational comparison of developed instruments related to the CIO role identified from the literature (e.g., McCall and Segrist (1980); Arthur Andersen Company (1986) cited in Passino Jr and Severance (1988); Karimi et al. (1996); Gottschalk (2000b); Smaltz et al. (2006); and Chen et al. (2011)) This scale was used to identify the perceived importance of six key CIO roles proposed as Strategist, Integrator, Relationship Architect, Educator, 
Utility Provider, and Information Steward. As explained earlier, there are two main reasons for the choice of this instrument. Firstly, this instrument has demonstrated high validity and reliability (Chen and Wu 2011; Li et al. 2012; Wu et al. 2008). Secondly, this instrument is concise which is crucial as the targeted survey respondent is the most senior IT executive in the organisation and extremely busy, over surveyed and is unlikely to fill out a lengthy questionnaire.

The third section of the questionnaire includes questions regarding the participants' demographic details including their reporting structure and job title.

\section{DATA COLLECTION}

Data for this research were collected through a large scale mail survey carried out in Australia in early 2012. A list of postal addresses of 954 senior IT executives in Australian private sector firms was purchased from Dun \& Bradstreet Australia (2011) and provided the basis for the survey working population for this study. The mail survey was administrated in two waves: an initial mail out and a follow up mail out to ensure reasonable response rate. In February 2012 a cover letter along with a copy of the questionnaire and pre-paid reply envelope was sent to the senior IT executives' addresses. Table 8 provides some statistics regarding the survey administration.

\begin{tabular}{|l|l|l|l|l|l|l|l|}
\hline Round & Sent & Date & Responses & $\begin{array}{l}\text { Complete } \\
\text { and } \\
\text { usable }\end{array}$ & Incomplete & R.T.S. & $\begin{array}{l}\text { Not willing to } \\
\text { participate }\end{array}$ \\
\hline One & 954 & $28 / 2 / 2012$ & 97 & 95 & 2 & 105 & 4 \\
\hline Two & 950 & $19 / 3 / 2012$ & 67 & 67 & - & 105 & 1 \\
\hline Total & 1908 & & 164 & 162 & 2 & 210 & 5 \\
\hline
\end{tabular}

Table 8 Survey Administration Statistics

A total of 105 questionnaires were returned as undeliverable due to invalid addresses, and emails were received from five firms not willing to participate in this survey. With 162 complete and usable responses the response rate of this study was estimated to be 19.19 per cent which is considered to be a reasonable response rate for a postal mail survey compared to similar studies involved CIOs where response rates ranged from 7 to 22.5 per cent (Chen and Wu 2011; Gerow 2012; Oh and Pinsonneault 2007; Preston et al. 2006; Weiss and Adams 2010; Wu et al. 2008).

\section{DATA ANALYSIS}

\section{Measure Validation}

The validity and reliability of the CIO roles instrument developed by Smaltz et al. (2006) was checked prior to any further inferential analyses. This step is not applicable for the strategic IT vision scale as it is a single item ordinal measure. The data collected were analysed using component-based structural equation modelling method (SEM), partial least squares (PLS). Hair, Ringle, and Sarstedt (2012) asserted that PLS/SEM is more favourable with smaller sample sizes. The CIO roles were modelled as reflective constructs; hence five major areas should be tested to ensure measurement validity (Henseler, Ringle, and Sinkovics 2009): reliability at the construct level; reliability at the indicators level; convergent validity; discriminant validity at the construct level; and discriminant validity at the 
indicators level. PLS- Graph (version 03.12 Build 01) software was used to test the measurement (outer) model.

Following common criteria suggested by Chin (2010); and Henseler et al. (2009) we examined the inter-construct correlations, composite reliabilities, average variance extracted for each construct, item loadings on their constructs and items cross loadings on other constructs. These statistics are presented in Tables 9 and 10.

\begin{tabular}{|c|c|c|c|c|c|c|c|c|}
\hline Construct* & CR & AVE & Strategist & $\begin{array}{l}\text { Relationship } \\
\text { Architect }\end{array}$ & Integrator & Educator & $\begin{array}{l}\text { Utility } \\
\text { Provider }\end{array}$ & $\begin{array}{l}\text { Info. } \\
\text { Steward }\end{array}$ \\
\hline Strategist & 0.88 & 0.55 & $0.74^{* *}$ & & & & & \\
\hline $\begin{array}{l}\text { Relationship } \\
\text { Architect }\end{array}$ & 0.88 & 0.71 & 0.34 & 0.84 & & & & \\
\hline Integrator & 0.83 & 0.55 & 0.52 & 0.33 & 0.74 & & & \\
\hline Educator & 0.90 & 0.76 & 0.56 & 0.26 & 0.48 & 0.87 & & \\
\hline $\begin{array}{l}\text { Utility } \\
\text { Provider }\end{array}$ & 0.84 & 0.57 & 0.22 & 0.32 & 0.45 & 0.22 & 0.75 & \\
\hline $\begin{array}{l}\text { Info. } \\
\text { Steward }\end{array}$ & 0.81 & 0.59 & 0.46 & 0.43 & 0.40 & 0.44 & 0.43 & 0.77 \\
\hline
\end{tabular}

Table 9 Inter-Correlation among CIO Roles and Reliability Coefficients

As can be seen in Table 9, the composite reliability (CR) for all constructs exceeds the satisfactory level of 0.7 proposed by Werts, Linn, and Joreskog (1974) which supports internal consistency reliability. Reliability at the indicators level can be checked by examining the items loading on their respective constructs (see Table 10). Chin (1998) and Henseler (2009) suggested 0.7 as a rule of thumb for a standardized outer loading to ensure that the indicator has captured at least half of the variance. The factor loadings of all items exceed the standardized cut off except for five items of which three are over 0.6 and two are below 0.4. A decision was made to keep the first three items as long as the composite reliability for their respective constructs is still over the satisfactory level of 0.7 (Henseler et al. 2009) and remove the two items with the lower factor loadings of less than 0.4. The average variances extracted (AVEs) proposed by Fornell and Larcker (1981) for all research constructs as shown in Table 9 exceed the acceptable cut off 0.5 which indicates sufficient convergent validity.

Discriminant validity at the indicators level is evident in Table 10 as all remaining items are strongly related (loadings) to the constructs they were intended to measure and they do not have a stronger connection with another construct (cross loadings). Discriminant validity at the construct level is confirmed, as the square root of the AVE values of all constructs are larger than the inter-correlation of the constructs in the model which means that all constructs shared more variance with their own measures than with others (see Table 9). Since the reliability and validity of each construct for the six CIO roles was confirmed, the mean for each set of items retained for each of the six CIO roles was calculated in order to perform the ANOVA and correlation analysis required for the hypotheses testing. 


\begin{tabular}{|l|l|l|l|l|l|l|}
\hline Items & Strategist & Integrator & $\begin{array}{l}\text { Relationship } \\
\text { Architect }\end{array}$ & Educator & $\begin{array}{l}\text { Utility } \\
\text { Provider }\end{array}$ & $\begin{array}{l}\text { Information } \\
\text { Steward }\end{array}$ \\
\hline Stra1 & 0.67 & 0.32 & 0.27 & 0.32 & 0.35 & 0.11 \\
\hline Stra2 & 0.74 & 0.53 & 0.26 & 0.39 & 0.35 & 0.25 \\
\hline Stra3 & 0.75 & 0.48 & 0.25 & 0.38 & 0.29 & 0.25 \\
\hline Stra4 & 0.76 & 0.54 & 0.36 & 0.54 & 0.41 & 0.24 \\
\hline Stra5 & 0.78 & 0.26 & 0.23 & 0.43 & 0.35 & 0.05 \\
\hline Stra6 & 0.76 & 0.20 & 0.17 & 0.40 & 0.29 & 0.30 \\
\hline Integ1 & 0.45 & 0.75 & 0.21 & 0.25 & 0.42 & 0.49 \\
\hline Integ2 & 0.37 & 0.64 & 0.25 & 0.46 & 0.26 & 0.24 \\
\hline Integ3 & 0.27 & 0.76 & 0.22 & 0.33 & 0.26 & 0.31 \\
\hline Integ4 & 0.46 & 0.81 & 0.31 & 0.42 & 0.24 & 0.28 \\
\hline ReAr1 & 0.25 & 0.26 & 0.81 & 0.13 & 0.28 & 0.20 \\
\hline ReAr2 & 0.33 & 0.32 & 0.90 & 0.30 & 0.37 & 0.30 \\
\hline ReAr3 & 0.29 & 0.26 & 0.82 & 0.22 & 0.45 & 0.30 \\
\hline Edu1 & 0.41 & 0.48 & 0.21 & 0.84 & 0.43 & 0.28 \\
\hline Edu2 & 0.55 & 0.4 & 0.24 & 0.88 & 0.35 & 0.10 \\
\hline Edu3 & 0.48 & 0.36 & 0.23 & 0.89 & 0.37 & 0.18 \\
\hline UtPr1 & 0.11 & 0.23 & 0.25 & 0.11 & 0.68 & 0.29 \\
\hline UtPr2 & 0.17 & 0.37 & 0.21 & 0.22 & 0.80 & 0.33 \\
\hline UtPr3 & 0.08 & 0.31 & 0.24 & 0.13 & 0.81 & 0.34 \\
\hline UtPr4 & 0.33 & 0.45 & 0.27 & 0.19 & 0.73 & 0.35 \\
\hline InfSt2 & 0.36 & 0.41 & 0.41 & 0.30 & 0.40 & 0.70 \\
\hline InfSt3 & 0.44 & 0.33 & 0.36 & 0.43 & 0.29 & 0.78 \\
\hline InfSt4 & 0.26 & 0.19 & 0.24 & 0.28 & 0.31 & 0.81 \\
\hline & & & & & & R \\
\hline
\end{tabular}

Table 10 Six CIO Roles Construct's Items Loadings and Cross loadings (Source: PLS Results)

\section{Non-response Bias Test}

In order to assess non-response bias and following the guidelines presented in Armstrong and Overton (1977) and Sivo, Saunders, Chang, and Jiang (2006) a comparison was conducted between the early respondents $(\mathrm{N}=21)$ and late respondents $(\mathrm{N}=13)$ in terms of the research variables. It is assumed that late responders share similarities with non-responders and, if no significant differences are found between early and late responses, the likelihood is strong that non-response bias did not occur. A MannWhitney $\mathrm{U}$ test was used for this purpose since the data comprise some categorical variables. The results of the Mann-Whitney U test conducted on 26 items (presented in Appendix B) found statistically significant differences in only one item which means that there are no major differences between early and late respondent CIOs. These results indicate the absence of non-response bias.

\section{Testing Research Hypotheses}

Having confirmed the reliability and validity of the research measures for the six key CIO roles and established the absence of non-response bias, the next stage of the data analysis involved splitting the total data set (162 responses) into four sub groups based on the organisation's strategic IT vision. These four groups across the 162 respondent organisations were: Automate (32); Informate-down (31); Informate-up (29); and Transform (70). These four groups provide the basis for testing the research hypotheses. Table 11 exhibits the mean and standard deviation of the six CIO roles for the overall sample and the subsamples of organisations grouped according to their vision of IT. 


\begin{tabular}{|c|c|c|c|c|c|c|c|c|c|c|}
\hline CIO Roles & $\begin{array}{l}\text { Overall } \\
\mathrm{N}=164 \\
\text { Mean }\end{array}$ & SD & $\begin{array}{l}\text { Auton } \\
\mathrm{N}=32 \\
\text { Mean }\end{array}$ & SD & $\begin{array}{l}\text { Inforn } \\
\mathrm{N}=31 \\
\text { Mean }\end{array}$ & $\begin{array}{l}\text { own } \\
\text { SD }\end{array}$ & $\begin{array}{l}\text { Inforr } \\
\mathrm{N}=29 \\
\text { Mean }\end{array}$ & $\begin{array}{l}\text { SD } \\
\text { SD }\end{array}$ & $\begin{array}{l}\text { Transt } \\
\mathrm{N}=70 \\
\text { Mean }\end{array}$ & SD \\
\hline Strategist & 5.37 & 0.98 & 5.1 & 0.99 & 5.29 & 1.06 & 5.27 & 1.21 & 5.58 & 0.79 \\
\hline $\begin{array}{l}\text { Relationship } \\
\text { Architect }\end{array}$ & 5.58 & 0.94 & 5.35 & 1.28 & 5.82 & 0.90 & 5.54 & 0.77 & 5.60 & 0.83 \\
\hline Integrator & 5.01 & 0.99 & 5.12 & 1.00 & 5.26 & 1.15 & 4.81 & 1.10 & 4.94 & 0.84 \\
\hline Educator & 4.79 & 1.20 & 4.28 & 1.42 & 4.95 & 1.09 & 4.78 & 1.33 & 4.97 & 1.03 \\
\hline $\begin{array}{l}\text { Information } \\
\text { Steward }\end{array}$ & 5.74 & 0.82 & 5.44 & 0.97 & 5.91 & 0.89 & 5.55 & 0.87 & 5.87 & 0.63 \\
\hline $\begin{array}{l}\text { Utility } \\
\text { Provider }\end{array}$ & 5.60 & 0.90 & 5.66 & 0.84 & 5.72 & 0.92 & 5.53 & 1.08 & 5.55 & 0.84 \\
\hline
\end{tabular}

Table 11 Descriptive Statistics for Six Key CIO Roles across Four IT Visions (Source: developed for this study)

\section{Testing Hypothesis One}

A one-way analysis of variance (ANOVA) was conducted to determine whether the means of the six key CIO roles differed across the four groups of IT vision. Results partially support research hypothesis one as they show that there are significant differences at the $\mathrm{p}<.05$ level among two of the six key CIO roles across the four groups of an organisation's IT vision. Next, to determine which CIO roles were significantly different across the four groups of IT vision, Tukey post-hoc comparisons of the four groups of IT visions were conducted and indicated that there are significant differences between the $\mathrm{CIO}$ role as an Educator in the firms that articulate a 'transform' vision $(\mathrm{M}=4.97, \mathrm{SD}=1.03)$ and those firms that articulate an 'automate' vision $(\mathrm{M}=4.28$, SD 1.42). Results also show that there are significant differences between the CIO role as an Information Steward in the firms that articulate an IT 'transform' vision $(\mathrm{M}=5.87, \mathrm{SD}=.64)$ and those firms that articulate an IT 'informate-down' vision $(\mathrm{M}=5.91, \mathrm{SD}=.90)$ and those firms that articulate an 'automate' vision $(\mathrm{M}=5.44, \mathrm{SD}=0.97)$. The effect size calculated using eta squared was 0.05 for the Educator role and 0.05 for the Information Steward role. According to Cohen (1988) the effect size of 0.05 can be considered a medium effect. Table 12 provides a summary of ANOVA results including Levene's tests for homogeneity which are all not significant at the $\mathrm{p}>.05$ level indicating that the population variance for each group are approximately equal.

\begin{tabular}{|l|l|l|l|l|}
\hline CIO Role & Levene Statistic & $\mathrm{F}(3,159)$ & Sig & Eta Squared \\
\hline Strategist & 1.86 n.s & 2.10 & 0.10 n.s & N.A \\
\hline Relationship Architect & 2.08 n.s & 1.35 & $0.25 n . s$ & N.A \\
\hline Integrator & 1.63 n.s & 1.28 & 0.28 n.s & N.A \\
\hline Educator & 2.28 n.s & 2.70 & $0.04^{*}$ & 0.05 \\
\hline Information Steward & 2.46 n.s & 3.06 & $0.03^{*}$ & 0.05 \\
\hline Utility Provider & 1.04 n.s & 0.37 & 0.77 n.s & N.A \\
\hline n.s = Not Significant; * Significant at p $<0.05$ & & \\
\hline
\end{tabular}

Table 12. ANOVA Results Regard the CIO Roles across Four IT visions 
The results shown in Table 12 partially support research hypothesis one.

\section{Testing Hypothesis Two}

In order to test the relationship between the CIO's structural power (job title and reporting structure) and the organisation's view of IT, and due to the ordinal nature of these variables, the authors ranked the data regarding the three research variables, strategic IT vision, CIO reporting structure, and CIO job title in a logical ordinal rank order from lowest to highest. This allowed us to perform a nonparametric correlation using Spearman's rank-order correlation. Table 13 illustrates how we recoded the research variables into ordinal rank order for the purpose of testing research hypothesis two.

\begin{tabular}{|l|l|l|l|l|}
\hline $\begin{array}{l}\text { Strategic IT } \\
\text { Vision }\end{array}$ & $\begin{array}{l}\text { CIO's Reporting } \\
\text { Structure }\end{array}$ & Common CIO's Job title & $\begin{array}{l}\text { Item } \\
\text { Rank }\end{array}$ & $\begin{array}{l}\text { Importance } \\
\text { Rank }\end{array}$ \\
\hline Automate & To Others & EDP / MIS Manager & 1 & Low \\
\hline $\begin{array}{l}\text { Informate- } \\
\text { down }\end{array}$ & To COO & IS/IT Manager/Director & 2 & Moderate \\
\hline Informate-up & To CFO & CTO & 3 & High \\
\hline Transform & To CEO & CIO / Vice President IT & 4 & Very High \\
\hline
\end{tabular}

Table 13 Ranking of Three Research Variables for Hypothesis Two

The total data set of 162 valid responses from Australian senior IT executives was used to test research hypothesis two. Spearman's rank-order correlation was performed between the three variables (Strategic IT vision, CIO reporting structure, and CIO job title). Results of the correlation analysis indicate that an organisation's strategic IT vision is significantly and positively associated with both the level of the CIO reporting structure ( $\mathrm{r}=.178, \mathrm{p}<.024,2$ tailed) and the level of the CIO job title in an organisation ( $\mathrm{r}=.207, \mathrm{p}<.008,2$ tailed). This finding supports the notion that the more progressively an organisation views IT from 'Automate' up to 'Transform', the more likely it is that the CIO will report to the upper level of senior management and will have higher level job title in an organisation. These results provide support for research hypothesis two. Table 14 shows descriptive statistics of a cross tabulation regarding the CIO's reporting structure and job title across four different contexts of IT vision which provide further support for the results of Spearman's rank-order correlation. As evidenced in Table 14 the percentage of IT leaders that reported to the most senior executive in an organisation (CEO) markedly increased from 34.4 per cent in firms that adopted the automate vision for IT to 52.9 per cent in firms that articulated the transform vision of IT. As shown in Table 14, it is worth mentioning that a comparison of the proportion of Australian CIOs reporting to the CEO with other surveys also conducted in Australia e.g., Watson (1990) and Leonard (2007) suggests a significant increase over time of CIOs reporting to the CEO. This percentage increased from 14 per cent in 1989 (Watson 1990), to 33 per cent in 2007 (Leonard 2007), to 42.7 per cent in 2012 in our study. 


\begin{tabular}{|c|c|c|c|c|c|c|c|c|c|c|}
\hline \multirow{2}{*}{$\begin{array}{l}\text { IT Visions } \\
\text { CIO Status }\end{array}$} & \multicolumn{2}{|c|}{$\begin{array}{l}\text { Overall } \\
\mathrm{N}=162\end{array}$} & \multicolumn{2}{|c|}{$\begin{array}{l}\text { Automate } \\
\mathrm{N}=32\end{array}$} & \multicolumn{2}{|c|}{$\begin{array}{l}\text { Informate- } \\
\text { down } \mathrm{N}=31\end{array}$} & \multicolumn{2}{|c|}{$\begin{array}{l}\text { Informate- up } \\
\mathrm{N}=29\end{array}$} & \multicolumn{2}{|c|}{$\begin{array}{l}\text { Transform } \\
\mathrm{N}=70\end{array}$} \\
\hline & Freq. & $\%$ & Freq. & $\%$ & Freq. & $\%$ & Freq. & $\%$ & Freq. & $\%$ \\
\hline $\begin{array}{l}\text { CIOReportin } \\
\text { gTo Other }\end{array}$ & 1 & 11.7 & 5 & 15.6 & 5 & 16.1 & 3 & 10.3 & 6 & 8.6 \\
\hline To The COO & 14 & 8.6 & 4 & 12.5 & 2 & 6.5 & 3 & 10.3 & 5 & 7.1 \\
\hline To The CFO & 60 & 37.0 & 12 & 37.5 & 14 & 45.2 & 12 & 41.4 & 22 & 31.4 \\
\hline To The CEO & 69 & 42.7 & 11 & 34.4 & 10 & 32.3 & 11 & 37.9 & 37 & 52.9 \\
\hline $\begin{array}{l}\text { CIO Job } \\
\text { Title: } \\
\text { EDP/ MIS } \\
\text { Manager }\end{array}$ & 12 & 7.4 & 4 & 12.5 & 3 & 9.67 & 1 & 3.4 & 4 & 5.7 \\
\hline $\begin{array}{l}\text { IS/IT } \\
\text { Manager }\end{array}$ & 71 & 43.8 & 16 & 50.0 & 16 & 51.6 & 14 & 48.2 & 25 & 35.7 \\
\hline CTO & 6 & 3.7 & 1 & 3.1 & 2 & 6.5 & 1 & 3.4 & 2 & 2.9 \\
\hline $\begin{array}{l}\mathrm{CIO} / \text { Vice } \\
\text { President IT }\end{array}$ & 73 & 45.1 & 11 & 34.3 & 10 & 32.3 & 13 & 44.8 & 39 & 55.7 \\
\hline
\end{tabular}

Table 14 CIO Reporting Structure / Job Title within the Context of Strategic IT Vision.

As far as the CIO job title is concerned, Table 14 shows that nearly two thirds of the IT leaders working within firms that articulated transform vision of IT have a senior job title (CIO, VP IT, and CTO) while only one third have the lowest job title such as IS/IT Manager/director and vice versa for the firms that articulated the automate vision of IT. Figure 2 summarises the results of testing the research hypotheses.

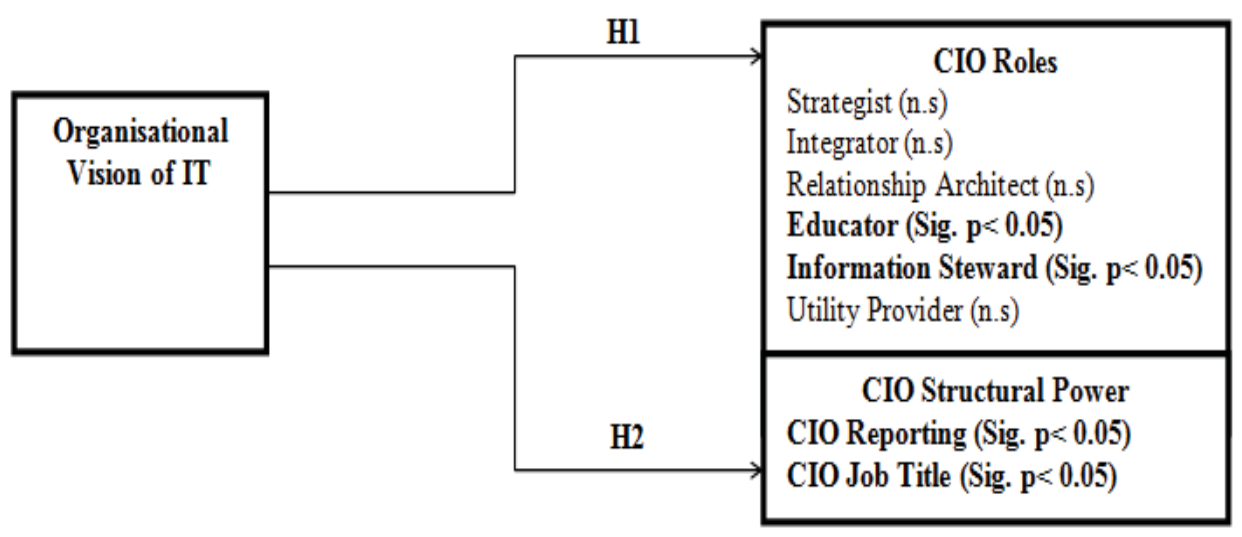

Figure 2. Summary of Outcomes of Research Hypotheses

\section{DISCUSSION}

Our study found that the importance of the six distinct CIO roles differs partially in regards to their organisation's strategic IT vision as perceived by their CIOs. The results of this study suggest that there is a significant effect of the IT vision of the firm on the CIO roles of Educator and Information Steward. 
The Australian CIOs who oversee IT in an organisation with a 'transform' vision of IT perceived the Educator and the Information Steward roles more important than other CIO roles in comparison to those who work within organisations with an 'automate' IT vision. The Information Steward was also perceived to be more important than the other roles by the CIOs within organisations with an 'informate-down' IT vision in comparison to those who work within organisations with an 'automate' IT vision.

The possible explanation for the importance of the CIO's Educator role in an organisation that adopted the 'transform' vision of IT might be due to the major cultural change required in firms going through transformational change (Schein 1989, 1992) which in turn requires the CIOs to pay more attention to the Educator role. The CIOs within organisations that articulate a 'transform' vision of IT need to perform two types of educational activities in order to promote IT as an agent of business transformation (Kadlec 2004). The first is the facilitating educational activities that are important to provide the top management team (TMT) with required knowledge regarding the emerging technology and how it can transform business (TMT mental model building). The second type of educational activities is empowerment activities which are important to provide the top management team with required knowledge regarding the established technologies used and how the firm can invest in these technologies to transform its business (TMT mental model maintenance). The importance of the CIO's Educator role in Australian firms that articulate the 'transform' vision of IT, provides further support for Pervan's (1998) finding that Australian CIOs have a greater need for the IT education of senior management. Also, the role of the CIO as an Information Steward in 'transform' vision organisations was found to be more important possibly because of the emerging concern of how to 'keep the lights on', and the need to provide high quality information, protect organisation data, customer privacy, and recruit qualified IT staff within the radical change brought about from adopting this transformational view of IT.

The same concern will emerge for CIOs who work within organisations that expressed the 'informatedown' vision of IT as according to Schein $(1989,1992)$ this view required the whole system to be transparent to employees which challenges the CIO's role as an Information Steward responsible for organisational data security and privacy.

Surprisingly, as the view of IT matures from 'automate' to 'transform' the strategic roles of the CIOs do not become more important which is consistent with the finding of Kaarst-Brown (2005) as she found that, despite the strategic potential of IT in the investigated organisations, the CIOs are often not granted the same strategic decision-making authority as other business executives. Also, these findings align with Grover et al.'s (1993) study which found that as IT matures the CIOs' strategic roles do not become more important as one might expect. On the other hand, those findings conflict with those of Smaltz (2000) who found an increase in the importance of the CIOs' strategic roles in organisations that expressed the 'transform' vision of IT. Two possible explanations are offered. Firstly, Smaltz (2000) conducted his research within the healthcare sector which has special characteristics, is information intensive and is still undergoing a continuous transformation process toward greater use of IT. The second explanation might be as the role of IT matures in an organisation, the other executives in the top management team will play a more proactive role in setting the IT strategic vision for the organisation.

Our study also found that IT leaders in organisations with transformational vision of IT are more powerful in terms of their job title and their reporting level than their counterparts in organisations that articulated lower visions of IT such as 'informate-up', 'informate-down' and 'automate' views. That means the IT leaders in organisations that articulated the higher transformational view of IT are more likely to have a higher level report to the CEO and hold the higher title of CIO or Vice President IT, whereas IT leaders in organisations that articulated a lower 'informate-up', 'informate-down' or an 'automate' view of IT are more likely have a lower level report to the CFO or COO and more likely to 
hold the lower title of CTO or IT /IS manager/director. These results are consistent with the results of Karimi et al. (1996); Grover et al. (1993); Raghunathan and Raghunathan (1989); Cohen and Dennis (2010); and Banker et al. (2011) who argued that the rank of the IT leaders should align with the firm's competitive strategy and IT orientation. Secondly these finding provide further support for the proposition developed by Sherer (2004) which argued that the reporting structure of IT leaders is influenced by the strategic vision of IT.

\section{CONCLUSION}

Our study has contributed to the body of knowledge in several ways. First, it is one of few studies that has examined the perceived importance of the configuration of CIO roles across organisations in relation to the different strategic views of IT and it presents some interesting results. Furthermore, the results of this study support the validity of the configuration of the CIO roles instrument developed by Smaltz et al. (2006) and indicate that this CIO roles configuration instrument is relevant to CIOs in different industries and not solely in the healthcare sector, which provides further support for the findings of Agarwal and Beath (2007) and Strickland (2011). The results provide support for the contingency approach to leadership confirming that when it comes to CIO roles, one size does not fit all organisations.

This study has several useful implications for different stakeholders. First, the findings of this study are important to CIOs as it is indicates the need to adapt their configuration of roles according to their organisation's strategic view of IT. Secondly, the key findings of this study can provide guidance to top management for recruitment of CIOs who will be able to play the configuration of roles that fit with the organisation's strategic view of IT. Moreover, the training programmes for the specialist institutions responsible for preparing CIOs can be enhanced by the key findings of this study regarding the need to consider a configuration of CIO roles that are aligned with organisation's strategic vision of IT. Furthermore, this study has highlighted some gaps in the literature. The vast majority of the literature was based on Mintzberg's framework (1973) whereas almost none have used the other three key management roles typologies such as PAIE (Adizes 1976, 2004); CVF (Quinn et al. 2006); and the integrated model of executive leadership roles (Hart and Quinn 1993).

\section{Limitations}

Despite the key findings reported from this study, some limitations should be acknowledged. The findings of this study represent the perceptions of Australian CIOs which might not match with the perceptions of CIOs in other countries. In addition, identifying the organisational view of IT is based on the perception of a single manager (the $\mathrm{CIO}$ ) rather than considering multiple perceptions (e.g. all top management team) hence the findings of this study regarding the relationship between the six CIO roles and the firm's IT vision should be treated with caution and investigated in greater detail from multiple perspectives of all the top management team.

\section{Future research}

The key findings and the gaps identified by this study warrant further research. First, studying the impact of the strategic IT vision on the configuration of CIO roles in different countries is needed in order to validate the generalizability of our study's findings and facilitate conducting a comparison among the IT leaders in different countries. Also, using different instruments whether for the CIO role or for the IT vision is required to better capture a comprehensive picture of the participants' perceptions in this area. Examining the relationship between the same constructs with a bigger sample size or extending the identification of the organisational view of IT to include other members of the firm's top management team could give different results. Finally, investigating the impact of other organisational 
contingencies such as organisational information intensity, organisational culture, organisational climate, organisational life cycle, and organisational IT maturity on the configuration of CIO roles is central to clarifying that vital role and filling the gaps in the body of knowledge. Finally, applying some neglected classic managerial roles configurations such as Adizes (1976,2004), Quinn et al. (2006) and Hart and Quinn (1993) could give another perspective and further insights regarding CIO roles.

\section{REFERENCES}

Adizes, I 1976, 'Mismanagement Styles', California Management Review, Vol. 19, No. 2, pp. 5-20.

Adizes, I 2004, Management/mismanagement styles, The Adizes Institute Publishing.

Agarwal, R \& Beath, C 2007, Grooming the 2010 CIO, A report for the Society for Information Management, Advanced Practice Council.

Armstrong, C, \& Sambamurthy,V 1999, 'Information technology assimilation in firms: The influence of senior leadership and IT infrastructures', Information Systems Research, Vol. 10, No. 4, pp. 304-27.

Armstrong, JS \& Overton, TS 1977, 'Estimating nonresponse bias in mail surveys', Journal of Marketing Research (JMR), Vol. 14, No. 3, pp. 396-402.

Banker, R, Hu, N, Pavlou, P, \& Luftman, J 2011, 'CIO Reporting Structure, Strategic Positioning, and Firm Performance', MIS Quarterly, Vol. 35, No. 2, pp. 487-504.

Bassellier, G, Reich, B, \& Bensabat, I 2001, 'Information technology competence of business managers: A definition and research model', Journal of Management Information Systems, Vol. 17, No. 4, pp. 159-82.

Broadbent, M, \& Kitzis, E. 2005, The new CIO leader: setting the agenda and delivering results, Harvard Business School Press.

Brown, C 1993, 'The successful CIO: integrating organizational and individual perspectives', paper presented to SIGCPR'93.

Brown, W 2006, 'CIO effectiveness in higher education', Educause Quarterly, Vol. 29, No. 1, p. 48.

Carter, M, Grover,V, \& Thatcher, J 2011, 'The Emerging CIO Role of Business Technology Strategist', MIS Quarterly Executive, Vol. 10, No. 1, pp. 19-29.

Cash, J, McFarlan, F, McKenney, J, \& Vitali, M 1988, Corporate Information Systems Management: Text and Cases, Homewood, IL: Irwin.

Chen, D, \& Preston, D 2007, 'Understanding CIO Role Effectiveness: The Antecedents and Consequents'. 40th Annual Hawaii International Conference on Systems Sciences, Jan. 2007.

Chen, D, Preston, D, \& Xia, W 2010, 'Antecedents and Effects of CIO Supply-Side and Demand-Side Leadership: A Staged Maturity Model', Journal of Management Information Systems, Vol. 27, No. 1, pp. 231-71.

Chen, D, Mocker, M, Preston, D, \& Tuebner, A 2010, 'Information systems strategy: reconceptualization, measurement, and implications', MIS Quarterly, Vol. 34, No. 2, pp. 23359.

Chen, Y, \& Wu, J 2011, 'IT management capability and its impact on the performance of a CIO', Information \& Management, Vol. 48, No. 4-5, pp. 145-56.

Chin, WW 1998, 'Issues and opinion on structural equation modelling', Management Information Systems Quarterly, Vol. 22, No. 1, pp. 7-16. 
Chin, W, W 2010, 'How to write up and report PLS analyses'. In V. Esposito Vinzi, W. W. Chin, J. Henseler, \& H. Wang (Eds.), Handbook of partial least squares: Concepts, methods and methods and application (pp. 645-689). New York.

Chun M , \& Mooney J. 2009, 'CIO roles and responsibilities: Twenty-five years of evolution and change', Information \& Management, Vol. 46, No. 6, pp. 323-34.

Cohen, J 1988, Statistical power analysis for the behavioral sciences, Lawrence Erlbaum.

Cohen, J \& Dennis, C 2010, 'Chief information officers: An empirical study of competence, organisational positioning and implications for performance', South African Journal of Economic and Management Sciences, Vol. 13, No. 2, pp. 203-21.

Dahlbom, B \& Mathiassen, L 1997, 'The future of our profession', Communications of the ACM, Vol. 40, No. 6, pp. 80-9.

Dun and Bradstreet 2011, Company 360 database, Dun and Bradstreet (Australia) Pty Ltd, viewed 10th June

2012

$<$ http://dnb.com.au/Sales_and_Marketing/Company_information_and_research/index.aspx $>$

Earl, M.J. (1996). The chief information officer: past, present and future. In: Earl, M.J., Information Management. Oxford University Press, Oxford.

Feeny, D 1997, 'The five year learning of ten IT directors', Managing IT as a strategic resource. Maidenhead: McGraw Hill.

Feeny, DF, Edwards, BR \& Simpson, KM 1992, 'Understanding the CEO/CIO relationship', MIS Quarterly, Vol. 16, No. 4, pp. 435-48.

Fiedler, F. 1967, A theory of leadership effectiveness. New York: McGraw-Hill

Fisher, JF 2003, 'CIO Then and Now: An historical perspective of the CIO role and the IT function', paper presented to 39 th Annual Meeting of the Midwest Business.

Fornell, C \& Larcker, DF 1981, 'Evaluating structural equation models with unobservable variables and measurement error', Journal of marketing research, Vol.18, February, pp. 39-50.

Gerow, JE 2012, 'What Should Firms Look for in a CIO?' Proceedings of the Southern Association for Information Systems Conference, Atlanta, GA, USA March 23-24.

Gottschalk, P 1999, 'Strategic management of IS/IT functions: the role of the CIO in Norwegian organisations', International Journal of Information Management, Vol. 19, No. 5, pp. 389-99.

Gottschalk, P. 2000a. The chief information officer: A study of managerial roles in Norway. [Electronic version]. Retrieved on April 14, 2011 from http://webster.hibo.no/okobit2000/idragsfiler/GOTTSCHALKP.doc

---- 2000b, 'Information systems executives: the changing role of new IS/IT leaders', Informing Science, Vol. 3, No. 2, pp. 31-40.

Grover, V, Jeong, S, Kettinger, W \& Lee, C 1993, 'The chief information officer: A study of managerial roles', Journal of Management Information Systems, Vol. 10, No. 2, pp. 107-30.

Hair, JF, Ringle, CM \& Sarstedt, M 2011, 'PLS-SEM: Indeed a silver bullet', Journal of Marketing Theory \& Practice, Vol. 19, No. 2, pp. 139-52.

Hallikainen, P, Hu, Q, Frisk, E, Päivärinta, T, Eikebrokk, TR \& Nurmi, A 2006, 'The use of formal IT investment evaluation methods in organizations: A survey of European countries'. Proceedings of the $12^{\text {th }}$ Americas Conference on Information Systems, Acapulco, Mexico August 4-6 2006.

Hart, SL \& Quinn, RE 1993, 'Roles executives play: CEOs, behavioral complexity, and firm performance', Human Relations, Vol. 46, No. 5, pp. 543-74.

Henseler, J, Ringle, CM \& Sinkovics, RR 2009, 'The use of partial least squares path modelling in international marketing', Advances in international marketing, Vol. 20, No. 1, pp. 277-319. 
Hersey, P \& Blanchard, KH 1993, Management of organizational behavior: Utilizing human resources, Prentice-Hall, Inc.

House, R \& Mitchell, T 1974, 'Path-goal theory of leadership', Journal of Contemporary Business, Vol, 3, pp. 81-97.

Hu, N, Pavlou, P, \& Banker,R. 2004, 'IT Orientation, CIO reporting structure and Firm Performance: To Whom Should the CIO Report?'. Workshop on Information Systems and Economics (WISE).

IBM 2009, The new voice of the CIO: Insight from the global chief information officer study, IBM Corporation.

Kaarst-Brown, M 2005, 'Understanding an organization's view of the CIO: the role of assumptions about IT', MIS Quarterly Executive, Vol. 4, No. 2, pp. 287-301.

Kadlec, C 2004, 'Educator Roles of the CIO', paper presented to the 7th Annual Conference of the Southern Association for Information Systems.

Karimi, J, Gupta, Y \& Somers, T 1996, 'The congruence between a firm's competitive strategy and information technology leader's rank and role', Journal of Management Information Systems, Vol. 13, No. 1, p. 88.

Karlsen, JT, Gottschalk, P \& Andersen, ES 2002, 'Information technology management roles: A comparison of IT executives and IT project managers', Proceedings of the 35th Annual Hawaii International Conference on System Sciences (HICSS), 7-10 Jan. 2002.

Leonard, J 2007, 'Sharing a vision: comparing business and IS managers' perceptions of strategic alignment issues', Australian Journal of Information Systems, Vol 15, No.1,pp 95-112.

Li, D, Ding, F, \& Wu, J, "Innovative Usage of Information Systems: Does CIO Role Effectiveness Matter?" (2012). PACIS 2012 Proceedings. Paper 81.

Lineman, J 2006, The chief information officer in higher education: A study in managerial roles, $\mathrm{PhD}$ Dissertation, Capella University.

Marchand, DA 2007, 'Realizing IT Value: A Shared Responsibility between Senior Managers and the CIO', Information Resources Management Journal. No.147, May 2007.

Mark, D \& Monnoyer, E 2004, 'Next-generation CIOs', The McKinsey Quarterly, July. pp.2-8.

McCall, MW, \& Segrist, CA 1980, In pursuit of the manager's job: Building on Mintzberg, Center for Creative Leadership.

McFarlan, W. F., McKenny, J. L., \& Pyburn, P. 1983. "The Information Archipelago: Plotting a Course," Harvard Business Review. 1983 Jan-Feb; 61(1), pp. 145-156.

McLean, E \& Smits, S 1993, 'The I/S leader as innovator", Proceedings of the Twenty-Sixth Hawaii International Conference on System Sciences, 5-8 Jan 1993.

McLean, E \& Smits, S 2003, 'A role model of IS leadership', AMCIS 2003 Proceedings, pp. 1273-1282.

McLean, E \& Smits,S. 2012, Management, Leadership, and the Roles of the CIO. Retrieved 5 January, 2013, from < http://cob.unt.edu/itds/faculty/becker/BCIS5520/Readings/CIO_LeadershipMcLean-Smits-June\%202011_ED1.pdf>

Milliron, MT 2008, Management roles and the community college Chief Information Officer, ProQuest.

Mintzberg, H 1971, 'Managerial Work: Analysis From Observation', Management Science, Vol. 18, No. 2, pp. B-97-B110.

Mintzberg, H 1973, The nature of managerial work, Harper \& Row, New York.

Nicolet, T 2011, Leadership in higher education: The CIO role and the leadership team. $\mathrm{PhD}$ Dissertation, North Carolina University at Greensboro. 
Oh, W \& Pinsonneault, A 2007, 'On the assessment of the strategic value of information technologies: Conceptual and analytical approaches', MIS Quarterly, Vol. 31, No. 2, pp. 239-265.

Passino Jr, JH \& Severance, DG 1988, 'The changing role of the Chief Information Officer', Strategy \& Leadership, vol. 16, no. 5, pp. 38-42.

Peppard, J, Edwards, C \& Lambert, R 2011, 'Clarifying the ambiguous role of the CIO', MIS Quarterly Executive, Vol. 10, No. 1, pp. 31-44.

Periasamy, KP, \& Seow, A,'CIO: Business Executive or Technical Expert?, paper presented to SEARCC'98, Hong Kong Computer Society. Hong Kong.

Pervan, G. (1998). "How Chief Executive Officers in large Organizations view the Management of their Information Systems." Journal of Information Technology, Vol.13. No. 2, pp. 95-109.

Preston, D \& Karahanna, E 2009, 'How to develop a shared vision: The key to is strategic alignment', MIS Quarterly Executive, Vol. 8, No. 1, pp. 1-8.

Preston, DS, Karahanna, E \& Rowe, F 2006, 'Development of shared understanding between the Chief Information Officer and top management team in U.S. and French organizations: A crosscultural comparison', IEEE Transactions on Engineering Management, Vol. 53, No. 2, pp. 191206.

Preston, D, Chen, D \& Leidner, D 2008, 'Examining the antecedents and consequences of CIO strategic decision-making authority: An empirical study', Decision Sciences, Vol. 39, No. 4, pp. 605-42.

Quinn, R. E., \& Rohrbaugh, J. (1981). A competing values approach to organizational effectiveness. Public Productivity Review, Vol. 5, No. 2, Jun, pp.122-140.

Quinn, RE \& Rohrbaugh, J 1983, 'A spatial model of effectiveness criteria: Towards a competing values approach to organizational analysis', Management Science, Vol. 29, No. 3, pp. 363-77.

Quinn, R, Faerman, S, Thompson, M, McGrath, M \& Clair, L 2006, Becoming a master manager: A competing values approach, John Wiley \& Sons Inc.

Raghunathan, B \& Raghunathan, T 1989, 'Relationship of the rank of information systems executive to the organizational role and planning dimensions of information systems', Journal of Management Information Systems, Vol.6, No.1, pp. 111-126.

Ramakrishna, H \& Lin, X 2002, 'Perception of the role of information technology function in organizations: Toward the development of a measure', ACM SIGCPR Computer Personnel, Vol. 20, No. 4, pp. 39-54.

Richardson, VJ \& Zmud, RW 2002, 'The value relevance of information technology investment announcements: Incorporating industry strategic IT role', . Proceedings of the 35th Annual Hawaii International Conference on System Sciences (HICSS), 7-10 Jan. 2002.

Robbins, S, \& Duncan, R 1988, The role of the CEO and top management in the creation and implementation of strategic vision. D.C.Hambrik, ed., The executive effect: concepts and methods for studying top managers. JAI Press, Greenwich,CT.pp. 205-233.

Rockart, J, Ball, L \& Bullen, C 1982, 'Future role of the information systems executive', MIS Quarterly, Vol. 6, Special Issue, pp. 1-14.

Saldanha, T \& Krishnan, M 2011, "Leveraging IT for business innovation: Does the role of the CIO matter?”. Proceedings of the International Conference on Information Systems (ICIS) 2011

Sarbin, T. R., \& Allen, V. L. 1968 "Role theory." pp. 488-567 in Gardner Lindzey and Elliot Aronson (eds.), The Handbook of Social Psychology, Vol. I. Reading, Mass.: Addison-Wesley.

Schein, E.H. (1989), The Role of the CEO in the Management of Change: The Case of Information Technology, Sloan School of Management Working Paper Series, Paper \# 3072, Massachusetts Institute of Technology 1989. 
---- , (1992). The role of the CEO in the management of change: the case of information technology. In TA, Kochan and M. Useem (eds.). Transforming Organizations. Oxford: Oxford University Press, pp. 80-96.

Seddon, PB, Walker, D, Reynolds, P and Willcocks, L, 2008 "A Case-Based Assessment of the Descriptiveness of Three CIO Typologies and Validity of Two CIO-Effectiveness Models". ACIS 2008 Proceedings. Paper 90.

Sherer, SA 2004, 'IS project selection: the role of strategic vision and IT governance'. Proceedings of the 37th Annual Hawaii International Conference on System Sciences.

Sivo, SA, Saunders, C, Chang, Q \& Jiang, JJ 2006, 'How low should you go? Low response rates and the validity of inference in is questionnaire research', Journal of the Association for Information Systems, Vol. 7, No. 6, pp. 351-413.

Smaltz, D 2000, 'The elevation of CIO roles: organizational barriers and organizational enablers', Journal of healthcare information management: JHIM, Vol. 14, No. 1, pp. 81-91

Smaltz, D, Sambamurthy, V \& Agarwal, R 2006, 'The antecedents of CIO role effectiveness in organizations: An empirical study in the healthcare sector', IEEE Transactions on Engineering Management, Vol. 53, No. 2, pp. 207-22.

Smaltz, DH 1999, Antecedents of CIO effectiveness: A role-based perspective, Florida State University Tallahassee.

Sojer, M, Schläger,C, \& Locher, C, "The CIO - hype, science and reality" (2006).ECIS 2006 Proceedings. Paper 46, http://aisel.aisnet.org/ecis2006/46

Spitze, JM, \& dePaschalis, EG (2005), The “Quals” of the ideal CIO, SCC, Retrieved 28 June, 2012, from http://www.scc.cc/voice/CIO\%20Quals\%20Research\%20Report.pdf

Stephens, C, Ledbetter, W, Mitra, A \& Ford, F 1992, 'Executive or functional manager? The nature of the CIO's job', MIS Quarterly, Vol. 16, No. 4, pp. 449-67.

Stephens, CS 1995, The nature of information technology managerial work:The work life of five Chief Information Officers, Westport,CT, Quorum Books.

Straub, DW 1989, 'Validating Instruments in MIS Research', MIS Quarterly, Vol. 13, No. 2, pp. 147 69.

Strickland, S 2011, How the role of the chief information officer contributes to the organisation. University of Manchester.

Subramanian, GH \& Nosek, JT 1993, 'The development and validation of an instrument to measure perceived strategic value of information systems', , Proceeding of the Twenty-Sixth Hawaii International Conference on System Sciences, 5-8 Jan 1993.

Synnott, W 1987, The information weapon: winning customers and markets with technology, John Wiley \& Sons Inc.

Synnott, WR \& Gruber, WH 1981, Information resource management: Opportunities and strategies for the 1980s, John Wiley \& Sons, Inc

Tannenbaum, R \& Schmidt, WH 1958, 'How to choose a leadership pattern', Harvard Business Review, vol. March/April, pp. 95-102.

Tansley, D., Loughran, C., Edwards, C., Lambert, R. \& Peppard, J.. "Realizing Value from a CIO: Navigating the Silicon Ceiling," Deloitte LLP and Cranfield University Report, 2008, pp. 1-16.

Teo, TSH \& Too, BL 2000, 'Information systems orientation and business use of the internet: An empirical study', International Journal of Electronic Commerce, Vol. 4, No. 4, pp. 105-30.

Tripp, JF., "Transformational Focus in Strategic IT Vision: An Industry-Level Conceptual Model" (2008). MWAIS 2008 Proceedings. Paper 7. 
Venkataraman, N (ed.) 1991, "IT-Induced Business Reconfiguration” in MS Scott Morton ed. "The Corporation of the 1990's: Information Technology and Organisational Transformation", Oxford University Press, New York.

Vroom, VH \& Yetton, PW 1973, Leadership and decision-making, University of Pittsburgh Press, Pittsburgh, Penn.

Watson, R. T. (1990). "Influences on the IS Manager's Perceptions of Key Issues: Information Scanning and the Relationship with the CEO." MIS Quarterly, Vol. 14, No. 2, pp. 217-231.

Weill, P \& Broadbent, M 1998, Leveraging the New Iinfrastructure: How Market Leaders Capitalize on Information Technology, Harvard Business School Press, Boston.

Weiss, JW \& Adams, SM 2010, 'Changing roles of technology leaders: Strategic partners or high level mechanics?', 43rd Hawaii International Conference on System Sciences (HICSS), 5-8 Jan. 2010.

Weiss, JW., Thorogood, A., \& Clark, KD (2006). "Three IT-business alignment profiles: technical resource, business enabler, and strategic weapon." Communications of the Association for Information Systems 18: 676-691.

Werts, CE, Linn, RL \& Jöreskog, KG 1974, 'Intraclass reliability estimates: Testing structural assumptions', Educational and Psychological Measurement, Vol. 34, No. 1, pp. 25-33.

Wu, J-H, Chen, Y-C,; and Sambamurthy, V, 2008 "The Impacts of BTM Capability and CIO Role Effectiveness on Firms' Information Technology Assimilation: An Empirical Study" . ICIS 2008 Proceedings. Paper 76.

Yang, S 2008, The managerial roles of information technology manager: An Empirical Study of Financial Industry in Taiwan. Masters Thesis, National Taiwan University of Science and Technology.

Zmud, R 1988, Building relationships throughout the corporate entity, ICIT Press, Washington DC.

Zuboff, S 1985, 'Automate/informate: the two faces of intelligent technology', Organizational Dynamics, Vol. 14, No. 2, pp. 5-18. 


\section{APPENDIX A: EXTRACT FROM SURVEY QUESTIONNAIRE}

The full questionnaire is available on request from the authors.

1. The organisational strategic IT vision: which statement best describes the present vision of your top management team/executive staff of the role of information technology (IT) in your organization? (Tick one box only)

a) The potential of IT is cost saving or quality improvement through automation that is, the role of IT is to replace expensive, unreliable human labour, or at least transform its productivity.

b) The potential of IT is to empower employee driven performance improvement that is, the role of IT is to provide data and transactions that yield a far fuller picture at 'operator' level, with members of the staff gaining greater insight into their own activities.

c) The potential of IT is to transform the organisation - that is, the role of IT is to fundamentally change the organisation and/or industry through new products or services often including redefinition of relationships with our customers and/or suppliers.

d) The potential of IT is increased managerial control of the organisation - that is, the role of IT is to provide data and transactions that allow management more clear and organized views of the state and dynamics of the organisation.

2. The CIO Role: The following are general expectations that apply to the CIO role in varying degrees in organizations. Please indicate how important each expectation is in your organisation. (Tick one box only for each question)

Not

at all important
Critically important

\begin{tabular}{|l|l|l|l|l|l|l|l|l|l|}
\hline (a) Keep key systems operational. & 1 & 2 & 3 & 4 & 5 & 6 & 7 \\
\hline $\begin{array}{l}\text { (b) Establish and maintain an IT department that } \\
\text { is responsive to user requests/problems. }\end{array}$ & $\square$ & $\square$ & $\square$ & $\square$ & $\square$ & $\square$ & $\square$ \\
\hline $\begin{array}{l}\text { (c) Establish electronic linkages throughout the } \\
\text { organisation. }\end{array}$ & $\square$ & $\square$ & $\square$ & $\square$ & $\square$ & $\square$ & $\square$ \\
\hline $\begin{array}{l}\text { (d) Ensure the organization's users have } \\
\text { adequate workstations (PCs/Laptops/Tablets) to } \\
\text { accomplish their jobs. }\end{array}$ & $\square$ & $\square$ & $\square$ & $\square$ & $\square$ & $\square$ & $\square$ \\
\hline $\begin{array}{l}\text { (e) Establish electronic linkages to external } \\
\text { entities (customers, suppliers, partners, etc.). }\end{array}$ & $\square$ & $\square$ & $\square$ & $\square$ & $\square$ & $\square$ & $\square$ \\
\hline $\begin{array}{l}\text { (f) Direct efforts to build an integrated delivery } \\
\text { system. }\end{array}$ & $\square$ & $\square$ & $\square$ & $\square$ & $\square$ & $\square$ & $\square$ \\
\hline $\begin{array}{l}\text { (g) Build and maintain an IT staff with skill sets } \\
\text { that match your current and planned technology } \\
\text { base. Champion digital literacy throughout the }\end{array}$ & $\square$ & $\square$ & $\square$ & $\square$ & $\square$ & $\square$ & $\square$ \\
\hline $\begin{array}{l}\text { (h) Chame } \\
\text { organisation. }\end{array}$ & $\square$ & $\square$ & $\square$ & $\square$ & $\square$ & $\square$ & $\square$ \\
\hline $\begin{array}{l}\text { (i) Provide insight to the top management } \\
\text { team/executive staff (TMT) on new emerging } \\
\text { technologies. }\end{array}$ & $\square$ & $\square$ & $\square$ & $\square$ & $\square$ & $\square$ & $\square$ \\
\hline
\end{tabular}




\begin{tabular}{|c|c|c|c|c|c|c|c|}
\hline $\begin{array}{l}\text { (j) Assist top management team/executive staff } \\
\text { (TMT) in improving their digital literacy. }\end{array}$ & $\square$ & $\square$ & $\square$ & $\square$ & $\square$ & $\square$ & $\square$ \\
\hline $\begin{array}{l}\text { (k) Migrate organisation from legacy, } \\
\text { departmental applications to cross-departmental, } \\
\text { integrated applications. }\end{array}$ & $\square$ & $\square$ & $\square$ & $\square$ & $\square$ & $\square$ & $\square$ \\
\hline $\begin{array}{l}\text { (l) Develop/acquire an electronic document } \\
\text { management capability throughout the organisation. }\end{array}$ & $\square$ & $\square$ & $\square$ & $\square$ & $\square$ & $\square$ & $\square$ \\
\hline $\begin{array}{l}\text { (m) Develop an understanding of the industry } \\
\text { delivery process. }\end{array}$ & $\square$ & $\square$ & $\square$ & $\square$ & $\square$ & $\square$ & $\square$ \\
\hline $\begin{array}{l}\text { (n) Provide executive oversight for all IT } \\
\text { contracts with external vendors. }\end{array}$ & $\square$ & $\square$ & $\square$ & $\square$ & $\square$ & $\square$ & $\square$ \\
\hline $\begin{array}{l}\text { (o) Negotiate with vendor IT organizations on } \\
\text { new external contract proposals. }\end{array}$ & $\square$ & $\square$ & $\square$ & $\square$ & $\square$ & $\square$ & $\square$ \\
\hline $\begin{array}{l}\text { (p) Ensure IT contracts with external vendors } \\
\text { remain within scope and budget. }\end{array}$ & $\square$ & $\square$ & $\square$ & $\square$ & $\square$ & $\square$ & $\square$ \\
\hline $\begin{array}{l}\text { (q) Develop and implement a strategic IT plan } \\
\text { that aligns with the organisation's strategic business } \\
\text { plan. }\end{array}$ & $\square$ & $\square$ & $\square$ & $\square$ & $\square$ & $\square$ & $\square$ \\
\hline $\begin{array}{l}\text { (r) Develop/maintain metrics that measure the } \\
\text { value of IT to the organisation. }\end{array}$ & $\square$ & $\square$ & $\square$ & $\square$ & $\square$ & $\square$ & $\square$ \\
\hline $\begin{array}{l}\text { (s) Direct IT-enabled business process } \\
\text { restructuring/ reengineering. }\end{array}$ & $\square$ & $\square$ & $\square$ & $\square$ & $\square$ & $\square$ & $\square$ \\
\hline $\begin{array}{l}\text { (t) Provide expertise on multidisciplinary } \\
\text { business process improvement teams. }\end{array}$ & $\square$ & $\square$ & $\square$ & $\square$ & $\square$ & $\square$ & $\square$ \\
\hline $\begin{array}{l}\text { (u) Interact often with non-IT managers } \\
\text { throughout the organisation. }\end{array}$ & $\square$ & $\square$ & $\square$ & $\square$ & $\square$ & $\square$ & $\square$ \\
\hline $\begin{array}{l}\text { (v) Be intimately involved in shaping the } \\
\text { mission/vision of the organisation. }\end{array}$ & $\square$ & $\square$ & $\square$ & $\square$ & $\square$ & $\square$ & $\square$ \\
\hline $\begin{array}{l}\text { (w) Be intimately involved in business strategic } \\
\text { planning and decisions. }\end{array}$ & $\square$ & $\square$ & $\square$ & $\square$ & $\square$ & $\square$ & $\square$ \\
\hline $\begin{array}{l}\text { (x) Provide oversight for quality assurance of } \\
\text { organisational data. }\end{array}$ & $\square$ & $\square$ & $\square$ & $\square$ & $\square$ & $\square$ & $\square$ \\
\hline $\begin{array}{l}\text { (y) Ensure confidentiality and security of } \\
\text { organisational data. }\end{array}$ & $\square$ & $\square$ & $\square$ & $\square$ & $\square$ & $\square$ & $\square$ \\
\hline
\end{tabular}

3- CIO Demographic Information: Please answer the following questions regarding yourself, your job and your organisation.

3-1. CIO Reporting Structure: To whom do you primarily report?

$\square_{1} \quad$ Chief Executive Officer (CEO)

$\square_{2} \quad$ Chief Financial Officer (CFO)

$\square_{3} \quad$ Chief Operating Officer (COO)

$\square_{4} \quad$ Other (please specify)

3-2. Job title: which of the following categories best describes your current job title?

$\square_{1} \quad$ IT/IS Manager 
$\square_{2}$ IT/IS Director

$\square_{3} \quad$ MIS Manager

$\square_{4} \quad$ EDP Manager

$\square_{5}$ CIO

$\square_{6}$ СТО

$\square_{7}$ Vice President IT

$\square_{8}$ Other (please specify) 
APPENDIX B: NON-RESPONSE BIAS TEST RESULTS (MANN-WHITNEY U TEST)

\begin{tabular}{|c|c|c|c|c|c|c|c|c|}
\hline Items & Group & $\mathrm{N}$ & $\begin{array}{l}\text { Mean } \\
\text { Rank }\end{array}$ & $\begin{array}{l}\text { Sum } \\
\text { of } \\
\text { Ranks }\end{array}$ & $\begin{array}{l}\text { Mann- } \\
\text { Whitney U }\end{array}$ & $\begin{array}{l}\text { Wilcoxon } \\
\text { W }\end{array}$ & z-score & $\begin{array}{l}\text { Asymp. } \\
\text { Sig. } \\
\text { (2-tailed) }\end{array}$ \\
\hline Stra1 & $\begin{array}{l}\text { Early } \\
\text { Late }\end{array}$ & $\begin{array}{l}21 \\
13\end{array}$ & $\begin{array}{l}17.26 \\
17.88\end{array}$ & $\begin{array}{l}362.50 \\
232.50\end{array}$ & 131.50 & 362.50 & -0.19 & 0.84 \\
\hline Stra2 & $\begin{array}{l}\text { Early } \\
\text { Late }\end{array}$ & $\begin{array}{l}21 \\
13\end{array}$ & $\begin{array}{l}17.19 \\
18.00\end{array}$ & $\begin{array}{l}361.00 \\
234.00\end{array}$ & 130.00 & 361.00 & -0.24 & 0.81 \\
\hline Stra3 & $\begin{array}{l}\text { Early } \\
\text { Late }\end{array}$ & $\begin{array}{l}21 \\
13\end{array}$ & $\begin{array}{l}18.07 \\
16.58\end{array}$ & $\begin{array}{l}379.50 \\
215.50\end{array}$ & 124.50 & 215.50 & -0.45 & 0.65 \\
\hline Stra4 & $\begin{array}{l}\text { Early } \\
\text { Late }\end{array}$ & $\begin{array}{l}21 \\
13\end{array}$ & $\begin{array}{l}17.69 \\
17.19\end{array}$ & $\begin{array}{l}371.50 \\
223.50\end{array}$ & 132.50 & 223.50 & -0.14 & 0.88 \\
\hline Stra5 & $\begin{array}{l}\text { Early } \\
\text { Late }\end{array}$ & $\begin{array}{l}21 \\
13\end{array}$ & $\begin{array}{l}15.64 \\
20.50\end{array}$ & $\begin{array}{l}328.50 \\
266.50\end{array}$ & 97.50 & 328.50 & -1.43 & 0.15 \\
\hline Stra6 & $\begin{array}{l}\text { Early } \\
\text { Late }\end{array}$ & $\begin{array}{l}21 \\
13 \\
\end{array}$ & $\begin{array}{l}16.05 \\
19.85 \\
\end{array}$ & $\begin{array}{l}337.00 \\
258.00 \\
\end{array}$ & 106.00 & 337.00 & -1.12 & 0.26 \\
\hline Integ1 & $\begin{array}{l}\text { Early } \\
\text { Late }\end{array}$ & $\begin{array}{l}21 \\
13 \\
\end{array}$ & $\begin{array}{l}18.31 \\
16.19 \\
\end{array}$ & $\begin{array}{l}384.50 \\
210.50 \\
\end{array}$ & 119.50 & 210.50 & -0.62 & 0.53 \\
\hline Integ2 & $\begin{array}{l}\text { Early } \\
\text { Late }\end{array}$ & $\begin{array}{l}21 \\
13 \\
\end{array}$ & $\begin{array}{l}19.50 \\
14.27\end{array}$ & $\begin{array}{l}409.50 \\
185.50\end{array}$ & 94.50 & 185.50 & -1.54 & 0.12 \\
\hline Integ3 & $\begin{array}{l}\text { Early } \\
\text { Late }\end{array}$ & $\begin{array}{l}21 \\
13\end{array}$ & $\begin{array}{l}18.40 \\
16.04\end{array}$ & $\begin{array}{l}366.50 \\
208.50\end{array}$ & 117.50 & 208.50 & -0.69 & 0.48 \\
\hline Integ4 & $\begin{array}{l}\text { Early } \\
\text { Late }\end{array}$ & $\begin{array}{l}21 \\
13\end{array}$ & $\begin{array}{l}16.90 \\
18.46\end{array}$ & $\begin{array}{l}355.00 \\
240.00\end{array}$ & 124.00 & 355.00 & -0.46 & 0.64 \\
\hline ReAr1 & $\begin{array}{l}\text { Early } \\
\text { Late }\end{array}$ & $\begin{array}{l}21 \\
13\end{array}$ & $\begin{array}{l}20.38 \\
12.85\end{array}$ & $\begin{array}{l}428.00 \\
167.00\end{array}$ & 76.00 & 167.00 & -2.26 & $0.02 *$ \\
\hline ReAr2 & $\begin{array}{l}\text { Early } \\
\text { Late }\end{array}$ & $\begin{array}{l}21 \\
13\end{array}$ & $\begin{array}{l}19.71 \\
13.92\end{array}$ & $\begin{array}{l}414.00 \\
181.00\end{array}$ & 90.00 & 181.00 & -1.73 & 0.08 \\
\hline ReAr3 & $\begin{array}{l}\text { Early } \\
\text { Late }\end{array}$ & $\begin{array}{l}21 \\
13\end{array}$ & $\begin{array}{l}19.60 \\
14.12\end{array}$ & $\begin{array}{l}411.50 \\
163.50\end{array}$ & 93.50 & 183.50 & -1.63 & 0.10 \\
\hline Edu1 & $\begin{array}{l}\text { Early } \\
\text { Late }\end{array}$ & $\begin{array}{l}21 \\
13\end{array}$ & $\begin{array}{l}15.74 \\
20.35\end{array}$ & $\begin{array}{l}330.50 \\
264.50\end{array}$ & 99.50 & 330.50 & -1.36 & 0.17 \\
\hline Edu2 & $\begin{array}{l}\text { Early } \\
\text { Late }\end{array}$ & $\begin{array}{l}21 \\
13 \\
\end{array}$ & $\begin{array}{l}16.10 \\
19.77 \\
\end{array}$ & $\begin{array}{l}338.00 \\
257.00 \\
\end{array}$ & 107.00 & 338.00 & -1.08 & 0.27 \\
\hline Edu3 & $\begin{array}{l}\text { Early } \\
\text { Late }\end{array}$ & $\begin{array}{l}21 \\
13\end{array}$ & $\begin{array}{l}15.07 \\
21.42\end{array}$ & $\begin{array}{l}316.50 \\
278.50\end{array}$ & 85.50 & 316.50 & -1.88 & 0.06 \\
\hline UtPr1 & $\begin{array}{l}\text { Early } \\
\text { Late }\end{array}$ & $\begin{array}{l}21 \\
13\end{array}$ & $\begin{array}{l}18.79 \\
15.42\end{array}$ & $\begin{array}{l}394.50 \\
200.50\end{array}$ & 109.5 & 200.50 & -1.00 & 0.31 \\
\hline UtPr2 & $\begin{array}{l}\text { Early } \\
\text { Late }\end{array}$ & $\begin{array}{l}21 \\
13\end{array}$ & $\begin{array}{l}18.55 \\
15.81\end{array}$ & $\begin{array}{l}389.50 \\
205.50\end{array}$ & 114.50 & 205.50 & -0.81 & 0.41 \\
\hline UtPr3 & $\begin{array}{l}\text { Early } \\
\text { Late }\end{array}$ & $\begin{array}{l}21 \\
13\end{array}$ & $\begin{array}{l}18.38 \\
16.08\end{array}$ & $\begin{array}{l}386.00 \\
209.00\end{array}$ & 118.00 & 209.00 & -0.677 & 0.49 \\
\hline UtPr4 & $\begin{array}{l}\text { Early } \\
\text { Late }\end{array}$ & $\begin{array}{l}21 \\
13\end{array}$ & $\begin{array}{l}19.21 \\
14.73\end{array}$ & $\begin{array}{l}403.50 \\
191.50\end{array}$ & 100.50 & 191.50 & $\begin{array}{l}-1.30 \\
\end{array}$ & 0.19 \\
\hline InfSt2 & $\begin{array}{l}\text { Early } \\
\text { Late }\end{array}$ & $\begin{array}{l}21 \\
13\end{array}$ & $\begin{array}{l}17.57 \\
17.38\end{array}$ & $\begin{array}{l}369.00 \\
226.00\end{array}$ & 135.00 & 226.00 & -0.05 & 0.95 \\
\hline InfSt3 & $\begin{array}{l}\text { Early } \\
\text { Late }\end{array}$ & $\begin{array}{l}21 \\
13 \\
\end{array}$ & $\begin{array}{l}16.17 \\
19.65 \\
\end{array}$ & $\begin{array}{l}339.50 \\
255.50 \\
\end{array}$ & 108.50 & 339.50 & -1.02 & 0.30 \\
\hline
\end{tabular}




\begin{tabular}{|l|l|l|l|l|l|l|l|l|}
\hline InfSt4 & Early & 21 & 17.36 & 364.50 & 133.50 & 364.50 & -0.11 & 0.90 \\
& Late & 13 & 17.73 & 230.50 & & & & \\
\hline S.IT.V & Early & 21 & 15.36 & 322.50 & 91.50 & 322.50 & -1.72 & 0.08 \\
& Late & 13 & 20.96 & 272.50 & & & & \\
\hline CIO. & Early & 21 & 17.86 & 375.00 & 129.00 & 220.00 & -0.288 & 0.77 \\
J.T & Late & 13 & 16.92 & 220.00 & & & & \\
\hline CIO.R.S & Early & 21 & 16.07 & 337.50 & 106.50 & 337.50 & -1.12 & 0.26 \\
& Late & 13 & 19.81 & 257.50 & & & & \\
\hline
\end{tabular}

* Sig. $\mathrm{P}<0.05$ 